\section{ECONOMICS}

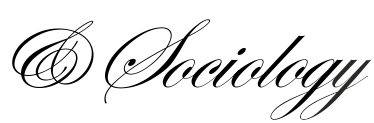

Al-Dalahmeh, M., \& Dajnoki, K. (2021). The influence of migration on the labour market status in Western European countries. Economics and Sociology, 14(3), 297-321. doi:10.14254/2071-789X.2021/14-3/16

\title{
THE INFLUENCE OF MIGRATION ON THE LABOUR MARKET STATUS IN WESTERN EUROPEAN COUNTRIES
}

\author{
Main Al-Dalahmeh \\ University of Debrecen, \\ Károly Ihrig Doctoral School of \\ Management and Business, \\ Debrecen, Hungary \\ Email: \\ maen.dalabmeb@econ.unideb.hu \\ ORCID 0000-0002-7761-1470

\section{Krisztina Dajnoki* \\ University of Debrecen, Faculty of Economics and Business, Institute of Management and Organization Sciences, Debrecen, Hungary \\ E-mail: \\ dajnoki.krisztina@,econ.unideb.bu *Corresponding author \\ ORCID 0000-0002-3340-5069}

Received: October, 2020

1st Revision: June, 2021

Accepted: September, 2021

DOI: $10.14254 / 2071-$

789X.2021/14-3/16

JEL Classification: J01, J08, J14, J15, J40
ABSTRACT. The purpose of the study is to indicate nativity status differences (native-born and foreign-born) by gender based on labour market status. The primary objective is to explore the labour market status differences in terms of nativity status based on a gender perspective of labour status. A quantitative research approach was applied to this study. Linear Regression analysis and Trend Analyses are used to emphasize the relationship between the native-born males/females and the foreign-born males/females in the labour market status as employed, unemployed and inactive. This study aims to answer which is higher in the case of native-born and foreign-born female/male employed, unemployed, and participation rates in Western-European countries. Data was collected from OECD (Organization for Economic Co-operation and Development) migration databases between 2014 and 2018 for Western European countries. It has been found that in the chosen countries, there is a linear relationship between native-born males/females and foreign-born males/females in most of the cases. If one side increases in terms of employed status or unemployed status, the other side also increases due to the existence of a significant and positive linear relationship. The findings suggest that this study implies that destination countries should create good labour market legislation to reduce the number of unemployed among both migrants and the native-born population. As very few studies have investigated gender differences in migration, this study gives a different perspective on the subject by comparing the same-gender relationship in the nativity status of the labour market.

Keywords: labour, migration, immigration, gender, linear regression 


\section{Introduction}

Migration is reshaping the European population socially, demographically, and economically, to the extent that migration has become a very important driving factor in these aspects (Sobotka, 2009; Al-Dalahmeh et al., 2021). In particular, Western European countries (The United Kingdom, France, The Netherlands, Germany, Spain, Portugal, Belgium, Austria, Switzerland, and Italy) have witnessed a vast growth in migration rates since World War II (Rangelova, 2009).In today's world, those countries have respectable population numbers, both of European and non-European origin. However, it is not always easy to indicate who is to be regarded as a migrant due to the lack of a definition to specify who has migrated or how far a person should go to be considered a migrant. Statistics concerning foreigners or foreign workers and employees make studying migration harder in Western European countries (Fassmann \& Munz, 1992). This is not the only issue, nor is it always an explicit one. However, it has always been one of the most essential indicators in defining migrants (Bither et al., 2019).

It has always been well-known that migration occurs due to the differences in the destination countries' geographic locations and economic situations. Along with this, high demand for labour from some destination countries, low wages, high unemployment, bad social security systems, and other push factors from the country of origin also create a potential labour migration flow to Western European countries (Stuhler et al., 2008 \& Dajnoki, et al., 2017).On the other hand, foreign labour is a function of economics and plays an essential role in economic policies and development (Freeman 1995; Freeman 2006). In this regard, a labour migration management system is essential for both origin and destination countries.

Raising new questions of labour migration is important and includes such issues as the relationship between the native-born employed and unemployed, the foreign-born employed and unemployed, and the participation rate of native/foreign-born male and female workers in the labour market. This article tries to identify nativity status differences and participation rates based on gender in the labour market. The research has been limited to Western European countries in the period from 2014 to 2018. Eastern European countries have not been included in the analysis as many migrants in these countries aim to travel to Western Europe when they get the opportunity (Jennissen and Van Wissen, 2015). Altogether, 10 Western European countries are included in this study.

Additionally, we analyse which considerations we should bear in mind when constructing models of labour migration, which can offer a more suitable analysis of the heterogeneity of gender differences in employed and unemployed statuses(Sarihasan, 2017 $\&$ Bachan, 2018). Thus, this article aims to answer these research questions:

1. Is the number of native-born employed males higher than that for foreign-born employed males in Western European countries?

2. Is the number of foreign-born unemployed males higher than that for the native-born male population in Western European countries?

3. Is the participation rate of native-born males in the labour sector higher than that for foreign-born males in Western European countries?

4. Is the number of native-born employed females higher than that for foreign-born females in Western European countries?

5. Is the number of foreign-born unemployed females higher than that for native-born females in Western European countries?

6. Is the participation rate of native-born females in the labour sector higher than that for foreign-born females in Western European countries?

In addition, in this study, the participation rate of males and females are also indicated and estimated by analyses. This paper is organized as follows. It starts by offering a brief 
description of the migration stream in Western European countries. Subsequently, the literature review focuses on the employed and unemployed aspects of migration and migration theories in constructing a picture of labour migration. In the data section, a statistical overview methodology is used, and time periods are presented. The results section of the study shows the empirical results obtained from testing the hypotheses of the article. Following this, the possible implications are introduced, and finally, the article ends with a conclusion.

\section{Literature review}

The expanding literature on migration focuses on employed and unemployed status, occupational attainments, and labour market segmentation participation rates (Hanson, 2009a \&Oláh, et al., 2017; Cseh Papp et al., 2018). Geographic mobility plays an essential role in determining the occupational distribution of economic activity in the host societies, where the foreign-born population has significant fiscal influences (Hempstead, 2007).In a simplistic sense, migration occurs as a response to employment opportunities and has an essential effect on the development of economic activities. In this sense, Basso and Peri (2020) also indicated that the foreign-born population plays a substantial role in distributing the labour market.

The neo-classical economic theory perspective indicates that labour market segmentation mainly consists of skill levels and jobs, cultural, socio-economic groups, and gender (Máté et al., 2018). This approach creates the migration market of the labour sector (Vadean et al., 2019). Moreover, dual labour and segmented labour market theory also supports the idea that socio-economic class and the occupations of migrants have more distribution effects than natives (Lucas, 2007) and also affect the employment opportunities of migrants (Rubery, 2015). There is also a sharp difference in age and gender when focusing on males and females separately. Borjas (2017) noted in his research that $3.4 \%$ more foreign-born males and females aged between 25 and 54 worked than did the native-born in the secondary sector. This percentage is higher when undocumented male and female migrants are taken into account. It has been documented that foreign-born females face significant economic and cultural obstacles to employment (Black et al., 2017; Al-Dalahmeh \& Dajnoki, 2021). These impediments might be greater than for natives, and they are unevenly distributed(Antecol and Heather 2000). On the other hand, migrant labour is undervalued by mechanisms such as the denial of formal and functional citizenship, cultural norms and institutional performance related to recognising foreign authorizations and experience (Bauder, 2006; Alshoubaki \& Harris, 2021). Furthermore, another essential point is that an individual's migration approach can have an imperative influence on their labour-market outcomes (Clark \& Drinkwater, 2008; Bilan, 2017).

On the other hand, human capital theory is another approach to explaining why migrants face discrimination in the labour market in the host countries. Based on this theory, skill configuration has led to migrants working in low-skill jobs and occupations(Máté et al., 2017). Perhaps educational attainment plays an essential role in these skills and the adaptation of the host countries' labour systems and sectors(Rendall \& Parker, 2014 \& Riphahn, 2018\& Werfhorst \& Heath, 2019). Those migrants with insufficient educational backgrounds have a lower chance of obtaining an employed position(Sarihasan, 2016). From this perspective, Hall and Farkas (2008) posited that it is also important to have language ability to eradicate barriers and create new opportunities for economic success. Communication is essential for obtaining information about jobs and performing job-related tasks (Gheasi \& Nijkamp, 2017).

Another reason why the native-born have more employment opportunities than the foreign-born is the average group differences in productivity-relevant characteristics (Cigagna $\&$ Sulis, 2015). For instance, foreign-born employees experience a wage discount relative to 
their labour productivity directly after migration but catch up in subsequent periods (Cangiano, 2014). The reduced likelihood of obtaining opportunities for the foreign-born can be explained by differences in human capital endowment and temporary adjustment problems with a prejudiced labour market (Faggian et al.,. 2017). On the other hand, any remaining disparity in earnings may be due to unobserved variables or due to discrimination (Lang 2000\&Lemmermann and Riphahn 2018). It is already a well-known fact that migrants experience descending occupational flexibility upon arrival in the destination country, relative to the position they had in their country of origin (Kang \& Kim, 2018). For instance, Bernard and Bell (2018)mentioned in their research that migrants experience a U-shaped pattern during their change from the labour market in the country of origin to the labour market in the country of destination(Ruhs et al.,., 2017). Thus, migrants generally experience downward mobility in the first occupational position they take after migration. Otherwise, gender-based job segmentation is still a popular theme for researchers. Female migrants in the labour market are more often employed in the informal sector or in low-paid work than male migrants. Even though they are skilled migrants, women are almost invisible in migration studies (Raghuram, 2008). The lack of policies for the protection of female migrants is also another reason why not much attention is paid to the economic activities of female migrants (Sarihasan, 2016). (Kofman, 2000 \&Bachan, 2018). Based on the above discussion, the hypotheses are:

H1: The native-born male population seems to be more employed than the foreign-born male population in Western European countries.

H2: The foreign-born male population is more likely to be unemployed than the nativeborn male population in Western European countries.

Also, excluding the infrequently appearing statistics on the gender breakdown of employment, there is not much discussion on the influence of female and gender relations on employment opportunities in destination countries. However, female migrants are usually seen as consumers and receivers of welfare rather than wage-earners $(\mathrm{H}$. Wang, Guo, \& Cheng, 2015). This situation also might make it harder to obtain an employment position than it is for the native-born female population in the receiving countries (Wang and Coulter, 2019).

H3: In Western European countries, if the native-born female employed number increases, the foreign-born female employed number increases in the labour market.

H4: In Western European countries, if the unemployed foreign-born female number increases, the unemployed native-born female number will also increase in the labour market.

\section{Methodological approach}

To achieve the aim of the study, a quantitative research approach is applied. Besides this, the study was supported by the positivist theoretical example. It primarily used numerical data obtained from a secondary database and interpreted with a statistical method (Remenyi, Williams, Money, \& Swartz, 2000). Data were collected from OECD (Organization for Economic Co-operation and Development) migration databases between 2014 and 2018. These data are collected based on population censuses of OECD countries for the 2000 census (OECD, 2020). However, not all OECD member countries are involved in this study. Ten Western-European countries, The United Kingdom, France, TheNetherlands, Germany, Spain, Portugal, Belgium, Austria, Switzerland, and Italy, are chosen for the analyses based on the large number of migrants they are currently hosting.

This study aims to demonstrate a comparison between native-born and foreign-born migrants regarding their employed and unemployed status and the differences in participation rates by gender and is structured on six different models. Employed status refers to those aged 15 years or over who have reported that they have worked in paid employment 
for at least one hour in the previous week or had a job but were absent from work during the reference week. Unemployedstatusrefers to people of working age who are without work and who are available for work and have taken definite steps to obtain work. Based on the OECD, the participation rate is calculated as the labour force divided by the total working-age population, defined as people aged 15 to 64 .

A Linear Regression model is used to analyze the relationship between the variables, and Trend analyses are conducted to show variables by year. In statistics, linear regression contains a model with a single explanatory variable, one independent variable and one dependent variable (Hidalgo \& Goodman, 2013). It is based on the fact that the outcome variable is related to only one predictor (Tanaka, Hayashi, \& Watada, 1989).

$$
Y=\alpha+b \mathrm{X}
$$

where $\mathrm{Y}$ is the dependent variable and $\mathrm{X}$ is the independent variable; thus, (b) is the slope of the line and (a) is they-retain. As mentioned before, six different models were used for this research. However, unlike other studies, this study gives a different perspective by comparing the same gender differences based on nativity status.

Model 1: The independent variable is employed native males, and the dependent variable is employed, foreign males.

Model 2: The independent variable is foreign-born unemployed males, and the dependent variable is the native-born male population.

Model 3: The independent variable is the participation rate of native-born males, and the dependent variable is the participation rate of foreign-born males.

Model 4: The independent variable is employed native females, and the dependent variable is employed, foreign females.

Model 5: The independent variable is foreign-born unemployed females, and the dependent variable is native-born females.

Model 6: The independent variable is the participation rate of native-born females, and the dependent variable is the participation rate of foreign-born females.

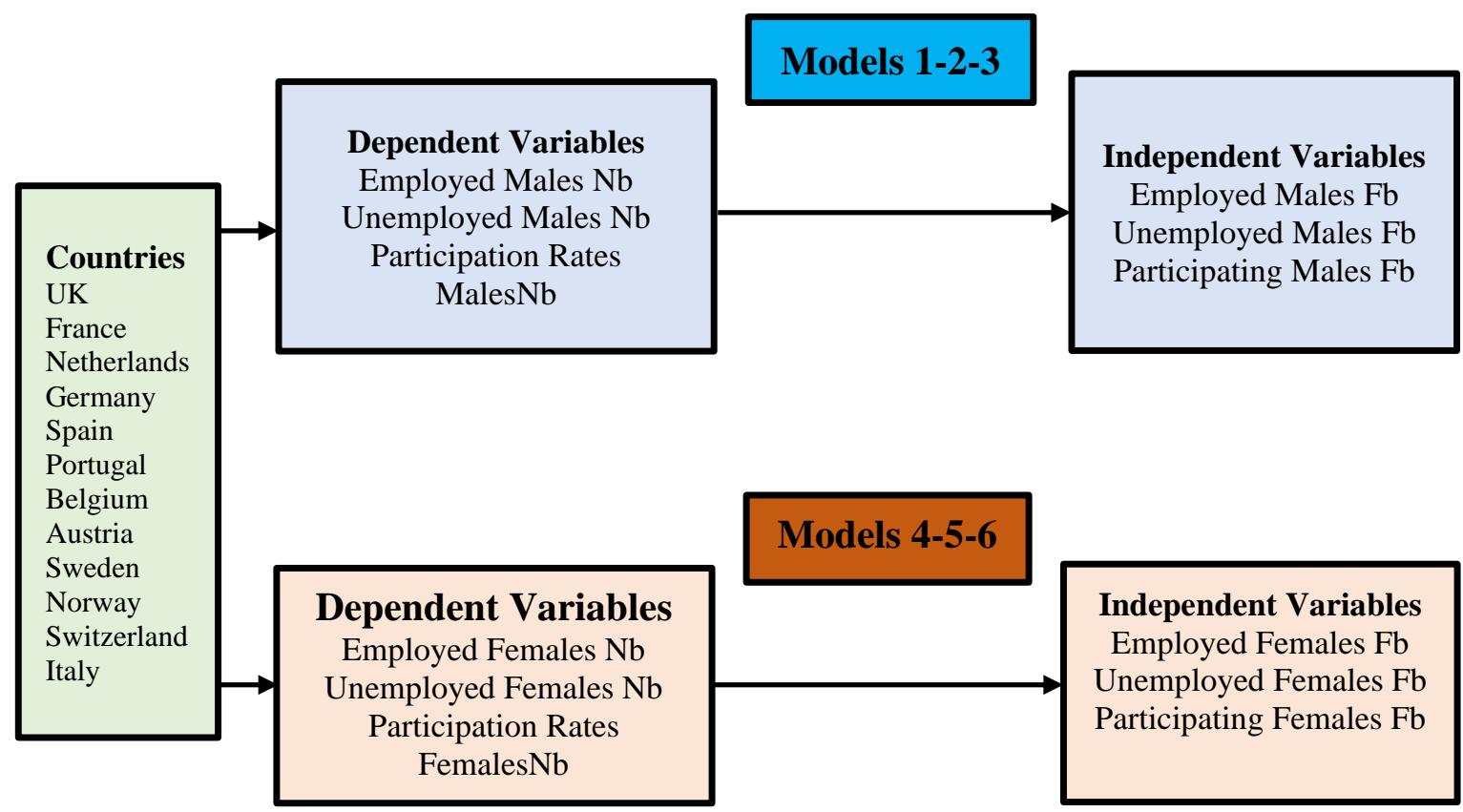

Figure 1. Applied research model of the study

Source: Author's own compilation (2020)

Note: $\mathrm{Nb}$ stands for Native-born and $\mathrm{Fb}$ for Foreign-born 


\section{Conducting research and results}

Our analysis raises major methodological and empirical challenges. The first is related to the lack of reliable data for migration that would permit researchers to achieve robust estimations and comparative analysis and the differences in the proxies typically used for migrants, particularly for gender-based analyses(Beck et al., 2012\&Bagavos, 2019). However, regression has been used in analyzing migration for some time; there has been substantial variation in the results from such studies of the quantitative construction of migration behaviour. This is partly due to the fact that correlations have been widely used in geographic, demographic and economic work on migration, not because researchers were primarily interested in correlations between the properties of areas as such, but because they wished to understand something about the behaviour of individuals(Willis, 1975).

Table 1 shows the relationship between native-born employed/unemployed and foreignborn employed/unemployed males. A bivariate regression is conducted in Model 1 to examine how foreign-born employed males could predict native-born employed males, and Model 2 indicates how native-born unemployed males could predict foreign-born unemployed males. The first estimations of Model 1 and Model 2 are related to the UK. The regression equation $\left(\mathrm{r}^{2}\right)$ for this is $0.826(\mathrm{p}<0.001)$, i.e., an $82.6 \%$ variance of native-born employed males from the UK was predictable from foreign-born employed males from the UK(Constant $=47.147$ and $\mathrm{B}=0.826$ ). This is a moderately strong relationship (Uyanık \& Güler, 2013). Based on the explanation, if the number of foreign-born employed males increases in the labour market, the number of native-born employed males also increases. Migration positively influences the labour supply by increasing the job opportunities in certain sectors by expanding the demand for labour (Jouke et al., 2019) and helps to create new jobs (Cornelson, 2016). Thus, if the number of foreign-born workers increases in the destination country, the number of native-born workers may also be rising.

On the other hand, as regards unemployment, the variables are positively and significantly interrelated. Based on the findings of the models, i.e. $\left(\mathrm{r}^{2}\right)=0.830$, there is an $83 \%$ $(\mathrm{p}<0.001)$ variance for native-born unemployed males' influence on foreign-born unemployed males(Constant $=-0.6319, \mathrm{~B}=0.911)$. If the number of native-born unemployed males rises in the UK's labour market, the number of foreign-born unemployed males will also increase in direct proportion.

The second row of the table characterizes the affiliation between French native-born employed males and foreign-born employed males. The dependent variable is foreign-born unemployed, and the independent variable is native-born unemployed male status. Based on the estimation $\left(\mathrm{r}^{2}\right)=0.751(\mathrm{p}<0.001)$, i.e., $75.1 \%($ Constant $=48.957, \mathrm{~B}=8.325)$, the result shows that in France, if the number of native-born employed males increases, the number of foreignborn employed males also grows. In the case of unemployed status, $\left(\mathrm{r}^{2}\right)=0.739(\mathrm{p}<0.001)$, i.e., $73.9 \%$ (Constant $=-2.2302, \mathrm{~B}=0.859$ ). This result demonstrates that if unemployment increases among native-born males in France, it will increase for foreign-born males, too.

In the case of Netherlands, where $\left(r^{2}\right)=0.506(p<0.001)$, i.e., $50.6 \%$ (Constant $=43.215$, $\mathrm{B}=0.711$ )the variables are associated with each other positively and significantly. Moreover, there is also a strong associationfor unemployed status $\left(\mathrm{r}^{2}\right)=0.883$, i.e., $88.3 \%(\mathrm{p}<0.001)$, (Constant $=0.2275, \mathrm{~B}=0.939)$. This result also demonstrates that in the Netherlands, if unemployed status increasesamong native-born males, it will also rise among foreign-born males. For other countries, regarding the associations between native-born employed males and foreign-born employed males, the variables associated with each otherpositively and significantly, as the following results indicate: Spain $\left(r^{2}\right)=0.979$, i.e. $97.9 \%(p<0.001)$ $($ Constant $=33.088, B=0.989)$, Portugal $\left(r^{2}\right)=0.954$, i.e.95.4\% $(p<0.001)($ Constant $=22.666$, 
$\mathrm{B}=0.976)$, Belgium $\left(\mathrm{r}^{2}\right)=0.616$, i.e. $61.6 \%(\mathrm{p}<0.001)($ Constant $=52.744, \mathrm{~B}=0.784)$, Austria $\left(\mathrm{r}^{2}\right)=0.548$, i.e. $54.8 \%(\mathrm{p}<0.001),($ Constant $=47.717, \mathrm{~B}=0.740)$ and Italy $\left(\mathrm{r}^{2}\right)=0.894$, i.e. 89.4 $\%(\mathrm{p}<0.001),($ Constant $=31.119, \mathrm{~B}=0.945)$. Inthese countries, if the number of foreign-born employed males increases, the number of native-born employed males will also grow.

It has been found that for unemployed foreign-born males and native-born employed males inSpain $\left(\mathrm{r}^{2}\right)=0.978$, i.e., $97.8 \%(\mathrm{p}<0.001),($ Constant $=-2.196, \mathrm{~B}=0.989)$ the explanatory variable has a strong influence on the dependent variable.Based on these findings, if the number of native-born unemployed males increases, the number of foreign-born unemployed males will also increase. This is also the case for Portugal $\left(r^{2}=0.924\right)$, i.e., $92.4 \%(p<0.001)$, (Constant $=-2.196, \mathrm{~B}=0.961)$, Belgium $\left(\mathrm{r}^{2}\right)=0.632$, i.e., $63.2 \%(\mathrm{p}<0.001),($ Constant $=0.501, \mathrm{~B}=0.796)$, Austria $\left(\mathrm{r}^{2}\right)=0.526$, i.e., $52.6 \%(\mathrm{p}<0.001),($ Constant $=3.005, \mathrm{~B}=0.726)$ and Italy $\left(\mathrm{r}^{2}\right)=0.865$, i.e., $86.5 \%(\mathrm{p}<0.001)$, (Constant $=-4.810, \mathrm{~B}=0.931)$. So, based on the findings, if native-born unemployment increases in the labour market, foreign-born unemployment will also rise. This conclusion was also reported in Castro-Martín \& Cortina (2015) in their research.

Table 1. Linear regression result of model 1 and model 2

\begin{tabular}{|c|c|c|c|c|c|c|c|c|}
\hline \multirow{2}{*}{$\begin{array}{l}\text { Dependent } \\
\text { Variables } \\
\end{array}$} & \multicolumn{4}{|c|}{ Model 1} & \multicolumn{4}{|c|}{ Model 2} \\
\hline & Constant & Beta & $\mathbf{R}^{2}$ & $\begin{array}{l}\text { Adjusted } \\
\mathbf{R}^{2}\end{array}$ & Constant & Beta & $\mathbf{R}^{2}$ & $\begin{array}{c}\text { Adjusted } \\
\mathbf{R}^{\mathbf{2}}\end{array}$ \\
\hline UK & $\begin{array}{c}4.147 * * * \\
(0.000) \\
\end{array}$ & $\begin{array}{c}0.826 * * * \\
(0.000) \\
\end{array}$ & 0.826 & 0.668 & $\begin{array}{c}-0.6319 \\
(0.240)\end{array}$ & $\begin{array}{c}0.911 * * * \\
(0.00) \\
\end{array}$ & 0.830 & 0.822 \\
\hline France & $\begin{array}{c}48.957 * * * \\
(0.000)\end{array}$ & $\begin{array}{c}8.325 * * * \\
(0.000) \\
\end{array}$ & 0.751 & 0.740 & $\begin{array}{c}-2.2302 \\
(0.333)\end{array}$ & $\begin{array}{r}0.859 * * * \\
(0.000) \\
\end{array}$ & 0.739 & 0.727 \\
\hline Netherlands & $\begin{array}{c}43.215^{* * * *} \\
(0.000)\end{array}$ & $\begin{array}{r}0.711 * * * \\
(0.000) \\
\end{array}$ & 0.506 & 0.484 & $\begin{array}{l}0.2275 \\
(0.755) \\
\end{array}$ & $\begin{array}{r}0.939 * * * \\
(0.000) \\
\end{array}$ & 0.883 & 0.878 \\
\hline Germany & $\begin{array}{c}89.949 * * * \\
(0.000)\end{array}$ & $\begin{array}{c}-0.141 \\
(-0.149)\end{array}$ & 0.022 & -0.020 & $\begin{array}{c}3.374 * * * \\
(0.000)\end{array}$ & $\begin{array}{c}0.943 * * * \\
(0.000)\end{array}$ & 0.889 & 0.885 \\
\hline Spain & $\begin{array}{c}33.088 * * * \\
(0.000)\end{array}$ & $\begin{array}{c}0.989 * * * \\
(0.000)\end{array}$ & 0.979 & 0.978 & $\begin{array}{c}-2.196 * * \\
(0.020)\end{array}$ & $\begin{array}{c}0.989 * * * \\
(0.000)\end{array}$ & 0.978 & 0.977 \\
\hline Portugal & $\begin{array}{c}22.666 * * * \\
(0.000)\end{array}$ & $\begin{array}{c}0.976 * * * \\
(0.000)\end{array}$ & 0.954 & 0.952 & $\begin{array}{c}-2.975 * * * \\
(0.004)\end{array}$ & $\begin{array}{c}0.961 * * * \\
(0.000)\end{array}$ & 0.924 & 0.920 \\
\hline Belgium & $\begin{array}{c}52.744 * * * \\
(0.000)\end{array}$ & $\begin{array}{c}0.784 * * * \\
(0.000)\end{array}$ & 0.616 & 0.599 & $\begin{array}{c}0.501 \\
(0.838)\end{array}$ & $\begin{array}{c}0.796 * * * \\
(0.000)\end{array}$ & 0.632 & 0.617 \\
\hline Austria & $\begin{array}{c}47.717 * * * \\
(0.000)\end{array}$ & $\begin{array}{c}0.740 * * * \\
(0.000) \\
\end{array}$ & 0.548 & 0.528 & $\begin{array}{c}3.005 * * \\
(0.070)\end{array}$ & $\begin{array}{r}0.726 * * * \\
(0.000) \\
\end{array}$ & 0.526 & 0.505 \\
\hline Switzerland & $\begin{array}{c}71.614 * * * \\
(0.000)\end{array}$ & $\begin{array}{l}0.310 \\
(0.131)\end{array}$ & 0.096 & 0.057 & $\begin{array}{l}4.828 * * \\
(0.022)\end{array}$ & $\begin{array}{l}0.050 \\
(0.229)\end{array}$ & 0.062 & 0.021 \\
\hline Italy & $\begin{array}{c}31.119 * * * \\
(0.000)\end{array}$ & $\begin{array}{c}0.945 * * * \\
(0.000)\end{array}$ & 0.894 & 0.889 & $\begin{array}{c}-4.810 * * * \\
(0.004)\end{array}$ & $\begin{array}{c}0.931 * * * \\
(0.000)\end{array}$ & 0.865 & 0.860 \\
\hline
\end{tabular}

Source: Author's own compilation (2020)

Note: Constant and Beta errors are reported with p-values. Letters in the upper index refer to significance: $* * *$ : significance at 1 per cent, $* *: 5$ per cent, *: 10 per cent. 
Table 2 of the study intends to demonstrate the participation rate based on the nativity status of males for WesternEuropean countries. Estimations of the analyses shows that for the Netherlands $\left(\mathrm{r}^{2}\right)=0.187$, i.e., $18.7 \%(\mathrm{p}<0.05)$, $($ Constant $=93.859, \mathrm{~B}=-0.4331)$, variables have a weak relationship due to the low $r^{2}$ range. On the other hand, Beta is negative but significant. This outcome indicates that, if the foreign-born male participation rate becomes higher, the native-born male participation rate will become lower. In Germany, where $\left(\mathrm{r}^{2}\right)=0.159$, i.e., $15.9 \%(\mathrm{p}<0.05),($ Constant $=95.334, \mathrm{~B}=-0.398)$, the variables associated with each other negatively but significantly. Thus, in Germany if the foreign-born male participation rate rises, the native-born male participation rate will reduce in the labour market. Additionally, in Spain $\left(\mathrm{r}^{2}\right)=0.246$, i.e. $24.6 \%(\mathrm{p}<0.001)$, (Constant $\left.=42.069, \mathrm{~B}=0.496\right)$, in Portugal $\left(\mathrm{r}^{2}\right)=0.369$, i.e. $36.9 \%,(\mathrm{p}<0.001),($ Constant $=45.864, \mathrm{~B}=0.608)$, in Austria $\left(\mathrm{r}^{2}\right)=0.555$, i.e. $55.5 \%,(\mathrm{p}<0.001)$, $($ Constant $=49.374, \mathrm{~B}=0.745)$, and in Italy $\left(\mathrm{r}^{2}\right)=0.479$, i.e. $47.9 \%(\mathrm{p}<0.001),($ Constant $=40.318$, $\mathrm{B}=0.692)$ the variables are significantly and positively related with each other.

Consequently, if the foreign-born male participation rate increases in the labour market, the native-born male participation will also grow in these countries.

Table 2. Results of the linear regression for model 3 (participation rates of males)

\begin{tabular}{|c|c|c|c|c|}
\hline \multirow{2}{*}{$\begin{array}{l}\text { Dependent } \\
\text { Variables }\end{array}$} & \multicolumn{4}{|c|}{ Model 3} \\
\hline & Constant & Beta & $\mathbf{R}^{2}$ & Adjusted $\mathrm{R}^{2}$ \\
\hline \multirow[t]{2}{*}{ UK } & $78.087 * * *$ & 0.176 & 0.031 & -0.011 \\
\hline & $(0.000)$ & $(0.400)$ & & \\
\hline \multirow[t]{2}{*}{ France } & $71.955 * * *$ & 0.194 & 0.038 & -0.004 \\
\hline & $(0.000)$ & $(0.352)$ & & \\
\hline \multirow[t]{2}{*}{ Netherlands } & $93.859 * * *$ & -0.433 & 0.187 & 0.152 \\
\hline & $(0.000)$ & $(0.030) * *$ & & \\
\hline \multirow{2}{*}{ Germany } & $95.334 * * *$ & $-0.398 * *$ & 0.159 & 0.122 \\
\hline & $(0.000)$ & $(0.048)$ & & \\
\hline \multirow[t]{2}{*}{ Spain } & $42.069 * * *$ & $0.496 * * *$ & 0.246 & 0.213 \\
\hline & $(0.004)$ & $(0.012)$ & & \\
\hline \multirow[t]{2}{*}{ Portugal } & $45.864 * * *$ & $0.608 * * *$ & 0.369 & 0.341 \\
\hline & $(0.000)$ & $(0.001)$ & & \\
\hline \multirow[t]{2}{*}{ Belgium } & $69.137 * * *$ & 0.164 & 0.027 & -0.015 \\
\hline & $(0.000)$ & $(0.433)$ & & \\
\hline \multirow[t]{2}{*}{ Austria } & $49.374 * * *$ & $0.745 * * *$ & 0.555 & 0.536 \\
\hline & $(\mathbf{0 . 0 0 0})$ & $(0.000)$ & & \\
\hline \multirow[t]{2}{*}{ Switzerland } & $81.785 * * *$ & 0.069 & 0.004 & -0.038 \\
\hline & $(0.000)$ & $(0.741)$ & & \\
\hline \multirow[t]{2}{*}{ Italy } & $40.318^{* * * *}$ & $0.692 * * *$ & 0.479 & 0.456 \\
\hline & $(0.000)$ & $(0.000)$ & & \\
\hline
\end{tabular}

Source: Author's own Compilation (2020)

Note: Constant and Beta errors are reported with p-values. Letters in the upper case refer to significance: $* * *$ : significance at 1 per cent, $* *: 5$ per cent, *: 10 per cent. The dependent variable is the participation rate of native-born males, while the independent variable is the participation rate of foreign-born males of the chosen countries.

Table 3 shows the results of the relationship between native-born employed females and foreign-born employed females, and Model 4 that of foreign-born unemployed and native-born unemployed females and how they influence in each other in Model 5. In the model, the 
dependent variable is native-born employed females, and the independent variable is foreignborn employed females. Based on the findings, in the $\boldsymbol{U} \boldsymbol{K}\left(\mathrm{r}^{2}\right)=0.764$, i.e. $76.4 \%$, $(\mathrm{p}<0,001)$ $($ Constant $=32.445, B=00.874)$, in the Netherlands $\left(r^{2}\right)=0.627$, i.e. $62.7 \%$, $(p<0.001)$, $($ Constant $=28.642, \mathrm{~B}=0.792)$, in Germany $\left(\mathrm{r}^{2}\right)=0.450$, i.e.45.0\%, $(\mathrm{p}<0.001),($ Constant $=$ 9.943, B=0.671), in Spain $\left(\mathrm{r}^{2}\right)=0.945$, i.e. $94.5 \%$, $(\mathrm{p}<0.001)$, (Constant $\left.=13.202, \mathrm{~B}=0.972\right)$, in Portugal $\left(\mathrm{r}^{2}\right)=0.803$, i.e. $80.3 \%,(\mathrm{p}<0.001)($ Constant $=11.815, \mathrm{~B}=0.896)$, in Belgium $\left(\mathrm{r}^{2}\right)=$ 0.711 , i.e. $71.1 \%,(p<0.001),($ Constant $=39.432, B=0.843)$, inAustria $\left(r^{2}\right)=0.704$, i.e.70.4\%, $(\mathrm{p}<0.001),($ Constant $=7.650, \mathrm{~B}=0.839)$, and in Switzerland $\left(\mathrm{r}^{2}\right)=0.151$, i.e. $15.1 \%,(\mathrm{p}<0.05)$, (Constant $=51.405 \mathrm{~B}=0.389$ ) variables are associated with each other positively and significantly. In this regardif the number of native-born employed females increases in the aforementioned countries, so will the number of foreign-born employed females.

Table 3. Results of model 4 and model 5 (employed and unemployed status females)

\begin{tabular}{|c|c|c|c|c|c|c|c|c|}
\hline & \multicolumn{4}{|c|}{ Model 4} & \multicolumn{4}{|c|}{ Model 5} \\
\hline & Constant & Beta & $\mathbf{R}^{2}$ & $\begin{array}{c}\text { Adjuste } \\
\text { d R }^{2}\end{array}$ & $\begin{array}{c}\text { Constan } \\
t\end{array}$ & Beta & $\mathbf{R}^{2}$ & $\begin{array}{c}\text { Adjuste } \\
\text { d R R }^{2}\end{array}$ \\
\hline UK & $\begin{array}{c}32.445^{* *} \\
* \\
(0.000)\end{array}$ & $\begin{array}{c}0.874 * * * \\
(0.000)\end{array}$ & $\begin{array}{c}0.76 \\
4\end{array}$ & 0.754 & $\begin{array}{l}1.450 * * \\
(0.052)\end{array}$ & $\begin{array}{c}0.849 * * * \\
* \\
(0.000)\end{array}$ & $\begin{array}{c}0.72 \\
1\end{array}$ & 0.709 \\
\hline France & $\begin{array}{c}55.460 * * \\
* \\
(0.000)\end{array}$ & $\begin{array}{c}0.230 \\
(0.267) \\
\end{array}$ & $\begin{array}{c}0.05 \\
3\end{array}$ & 0.011 & $\begin{array}{l}4.224 \\
(0.114)\end{array}$ & $\begin{array}{c}0.702 * * * \\
(0.000)\end{array}$ & $\begin{array}{c}0.49 \\
2\end{array}$ & 0.470 \\
\hline $\begin{array}{l}\text { Netherland } \\
\text { s }\end{array}$ & $\begin{array}{c}28.642 * * \\
* \\
(0.001)\end{array}$ & $\begin{array}{c}(0.792)^{* *} \\
* \\
(0.000)\end{array}$ & $\begin{array}{c}0.62 \\
7\end{array}$ & 0.611 & $\begin{array}{c}2.120 * * \\
* \\
(0.000)\end{array}$ & $\begin{array}{c}0.967 * * * \\
(0.000)\end{array}$ & $\begin{array}{c}0.93 \\
5\end{array}$ & 0.932 \\
\hline Germany & $\begin{array}{c}9.943 \\
(0.500)\end{array}$ & $\begin{array}{c}0.671 * * * \\
(0.000)\end{array}$ & $\begin{array}{c}0.45 \\
0\end{array}$ & 0.426 & $\begin{array}{c}1.512 * * \\
* \\
(0.004)\end{array}$ & $\begin{array}{c}0.905 * * * \\
(0.000)\end{array}$ & $\begin{array}{c}0.90 \\
4\end{array}$ & 0.810 \\
\hline Spain & $\begin{array}{c}13.202 * * \\
* \\
(0.0000 \\
\end{array}$ & $\begin{array}{c}0.972 * * * \\
(0.000)\end{array}$ & $\begin{array}{c}0.94 \\
5\end{array}$ & 0.943 & $\begin{array}{r}1.651 \\
(0.131) \\
\end{array}$ & $\begin{array}{c}0.982 * * * \\
(0.000)\end{array}$ & $\begin{array}{c}0.96 \\
3\end{array}$ & 0.962 \\
\hline Portugal & $\begin{array}{l}11.815 \\
(0.033)\end{array}$ & $\begin{array}{r}0.896 \\
(0.000)\end{array}$ & $\begin{array}{c}0.80 \\
3\end{array}$ & 0.795 & $\begin{array}{l}1.963 \\
(0.109)\end{array}$ & $\begin{array}{c}0.896 * * * \\
(0.000)\end{array}$ & $\begin{array}{c}0.80 \\
2\end{array}$ & 0.794 \\
\hline Belgium & $\begin{array}{l}39.432 \\
(0.000)\end{array}$ & $\begin{array}{c}0.843 \\
(0.000) \\
\end{array}$ & $\begin{array}{c}0.71 \\
1\end{array}$ & 0.699 & $\begin{array}{l}0.257 \\
(0.915)\end{array}$ & $\begin{array}{c}0.781 * * * \\
(0.000)\end{array}$ & $\begin{array}{c}0.60 \\
9\end{array}$ & 0.592 \\
\hline Austria & $\begin{array}{r}7.650 \\
(0.373) \\
\end{array}$ & $\begin{array}{c}0.839 * * * \\
(0.000)\end{array}$ & $\begin{array}{c}0.70 \\
4\end{array}$ & 0.692 & $\begin{array}{c}3.378^{* *} \\
* \\
(0.000) \\
\end{array}$ & $\begin{array}{r}0.071 \\
(0.735) \\
\end{array}$ & $\begin{array}{c}0.00 \\
5\end{array}$ & -0.038 \\
\hline $\begin{array}{l}\text { Switzerlan } \\
\text { d }\end{array}$ & $\begin{array}{c}51.405^{* *} \\
* \\
(0.001)\end{array}$ & $\begin{array}{l}0.389 * * \\
(0.054)\end{array}$ & $\begin{array}{c}0.15 \\
1\end{array}$ & 0.115 & $\begin{array}{c}8.540 * * \\
* \\
(0.000)\end{array}$ & $\begin{array}{l}0.030 \\
0.888\end{array}$ & 0.01 & -0.043 \\
\hline Italy & $\begin{array}{l}24.359 \\
(0.120)\end{array}$ & $\begin{array}{c}0.309 \\
(0.132)\end{array}$ & $\begin{array}{c}0.09 \\
5\end{array}$ & 0.056 & $\begin{array}{c}3.044 \\
(0.182)\end{array}$ & $\begin{array}{c}0.789 * * * \\
(0.000)\end{array}$ & $\begin{array}{c}0.62 \\
2\end{array}$ & 0.606 \\
\hline
\end{tabular}

Source: Author's own calculation (2020)

Note: Constant and Beta errors are reported with p-values. Letters in the upper index case refer to significance: $* * *$ : significance at 1 per cent, $* *: 5$ per cent, *: 10 per cent. Model 4 refers to the relationship between employed native-born females and employed foreign-born females. Model 5 indicates the relationship between unemployed native-born females and unemployed 
foreign-born females for the chosen countries. The dependent variable of Model 4 is employed native-born females and of Model 5 native-born unemployed females, since the independent variable is foreign-born unemployed females for both the models.

In Table 3, Model 5 estimates the relationship between foreign-born unemployed females and native-born unemployed females. In the model, the dependent variable is foreignborn unemployed females, and the independent variable is native-born unemployed females. Based on the findings, variablesare associated with each other positively and significantly in the following countries: $\mathbf{U K}\left(\mathrm{r}^{2}\right)=0.721$, i.e. $72.1 \%,(\mathrm{p}<0.001),($ Constant $=1.450, \mathrm{~B}=0.849)$, in France $\left(r^{2}\right)=0.492$, i.e. $49.2 \%,(p<0.001),($ Constant $=1.512, B=0.702)$, in the Netherlands $\left(r^{2}\right)=0.935$, i.e. $93.2 \%,(p<0.001)$, (Constant $\left.=2.120, B=0.967\right)$, in Germany $\left(r^{2}\right)=0.904$, i.e. 90.4\%, $(\mathrm{p}<0.001),($ Constant $=1.512, \mathrm{~B}=0.905)$, in Spain $\left(\mathrm{r}^{2}\right)=0.963$, i.e. $96.3 \%,(\mathrm{p}<0.001)$, $($ Constant $=1.651, \mathrm{~B}=0.982)$, in Portugal $\left(\mathrm{r}^{2}\right)=0.802$, i.e. $80.2 \%,(\mathrm{p}<0.001),($ Constant $=1.963$, $\mathrm{B}=0.896)$, in Belgium $\left(\mathrm{r}^{2}\right)=0.609$, i.e. $60.9 \%$, $(\mathrm{p}<0.001)$, (Constant $\left.=0.257, \mathrm{~B}=0.781\right)$ and in Italy $\left(\mathrm{r}^{2}\right)=0.622$, i.e. $62.2 \%,(\mathrm{p}<0.001)$, (Constant $\left.=3.044, \mathrm{~B}=0.789\right)$. In this regardif the number of native-born unemployed females increase in those countries, the number of foreignborn unemployed females will increase, too.

Table 4. Result of the linear regression for model 6 (participation rates of female)

\section{Dependent Variables Model 6}

\begin{tabular}{|c|c|c|c|c|}
\hline & Constant & Beta & $\mathbf{R}^{2}$ & Adjusted $\mathbf{R}^{2}$ \\
\hline \multirow[t]{2}{*}{ UK } & $38.145 * * *$ & $0.847 * * *$ & 0.718 & 0.705 \\
\hline & $(0.000)$ & $(0.000)$ & & \\
\hline \multirow[t]{2}{*}{ France } & $75.264 * * *$ & -0.195 & 0.038 & -0.003 \\
\hline & $(0.000)$ & $(0.350)$ & & \\
\hline \multirow[t]{2}{*}{ Netherlands } & $81.974 * * *$ & -0.088 & 0.008 & -0.035 \\
\hline & $(0.000)$ & $(0.673)$ & & \\
\hline \multirow[t]{2}{*}{ Germany } & $75.357 *$ & 0.001 & 0.000 & -0.043 \\
\hline & $(0.006)$ & $(0.993)$ & & \\
\hline \multirow[t]{2}{*}{ Spain } & $63.601 * * *$ & 0.156 & 0.025 & -0.018 \\
\hline & $(0.000)$ & $(0.454)$ & & \\
\hline \multirow[t]{2}{*}{ Portugal } & $34.707 * * *$ & $0.656 * * *$ & 0.430 & 0.406 \\
\hline & $(0.000)$ & $(0.000)$ & & \\
\hline \multirow[t]{2}{*}{ Belgium } & $42.361 * * *$ & $0.669 * * *$ & 0.448 & 0.423 \\
\hline & $(0.000)$ & $(0.000)$ & & \\
\hline \multirow[t]{2}{*}{ Austria } & $48.827 * * *$ & $0.486 * * *$ & 0.236 & 0.203 \\
\hline & $(0.000)$ & $(0.014)$ & & \\
\hline \multirow[t]{2}{*}{ Switzerland } & $52.224 * * *$ & $0.396 * *$ & 0.157 & 0.120 \\
\hline & $(0.001)$ & $(0.050)$ & & \\
\hline \multirow[t]{2}{*}{ Italy } & $45.739 * * *$ & 0.105 & 0.011 & -0.032 \\
\hline & $(0.014)$ & $(0.616)$ & & \\
\hline
\end{tabular}

Source: Author's own calculation (2020)

Note: Constant and Beta errors are reported with p-values. Letters in the upper index refer to significance: ***: significance at 1 per cent, **: 5 per cent, *: 10 per cent. The dependent variable is the participation rate of native-born females, while the independent variable is the participation rate of foreign-born females in the chosen countries. 
In Table 4, Model 6 evaluates the relationship between the participation rate of nativeborn unemployed females and foreign-born unemployed females. In the model, the dependent variable the participation rate of native-born females and the independent variable is foreignborn females. The results are as follows: the UK $\left(\mathrm{r}^{2}\right)=0.718$, i.e.71.8\%, $(\mathrm{p}<0.001)($ Constant $=$ 38.145, $\mathrm{B}=0.847)$, Portugal $\left(\mathrm{r}^{2}\right)=0.430$, i.e. $43.0 \%,(\mathrm{p}<0.001)($ Constant $=34.707, \mathrm{~B}=0.656)$, Belgium $\left(r^{2}\right)=0.448$, i.e. $44.8 \%,(p<0.001),($ Constant $=42.361, B=0.669)$, Austria $\left(r^{2}\right)=0.236$, i.e. $23.6 \%,(p<0.001)$, $($ Constant $=48.827 \mathrm{~B}=0.486)$, Switzerland $\left(\mathrm{r}^{2}\right)=0.157$, i.e. $15.7 \%$, $(\mathrm{p}<0.05),($ Constant $=52.224, \mathrm{~B}=0.396)$. Estimation of the analyses demonstrates that in the UK, Portugal, Belgium, Austria, Sweden and Switzerland if the participation rate increases among foreign-born females it will impact positively on native-born females, as well. Their participation rate will rise, too.

$\mathrm{H} 1$ indicated that the native-born male population seems to be more employed than the foreign-born male population in Western European countries. According to the results, in the UK, France, the Netherlands, Spain, Portugal, Belgium, Austria and Italy, if the number of native-born employed males increases, so does the number of foreign-born employed males. However, in Germany and Switzerland, there is no link shown. Due to this, H1 is partially rejected. $\mathrm{H} 2$ states that foreign-born males are more likely to be unemployed than native-born males in Western European countries. Based on the empirical tests, in the UK, France, the Netherlands, Germany, Spain, Portugal, Belgium, Austria and Italy, if the foreign-born male unemployment rate rises, then the native-born male unemployment rate also increases. There was no link found for Switzerland. Due to this, H2 is also partially rejected.

$\mathrm{H} 3$ attempted to establish whether, if the native-born female employed population increases, the foreign-born female population would also increase in Western European countries. The research findings show that in the UK, the Netherlands, Germany, Spain, Portugal, Belgium, Austria and Switzerland, if the native-born employed female population increases, the foreign-born female population will also increase. Regarding France and Italy, there is no relationship shown. Because of this, H3 is also partially accepted. H4 states that if foreign-born females become unemployed, native-born females will also become unemployed in Western European countries. The results indicate that in the UK, France, the Netherlands, Germany, Spain, Portugal and Italy, if the number of foreign-born unemployed females increases, the number of native-born unemployed females will also increase. Nevertheless, for Austria and Switzerland, no link was found. Based on this, H4 is partially accepted, too.

\section{Trend analyses}

Trend analysis often refers to techniques for extracting an underlying pattern of behaviour in a time series. Figure 1 shows the employment status of each country. Each country's status is explained separately below.

For instance, in the case of Austria, employment status generally shows an upward trend for foreign/native males and foreign/native females between 2014-2018.

Belgium (BEL)/Switzerland (CHE): The employment status of Belgium (BEL) and Switzerland (CHE) has upward trends for native-born males and females. However, in the case of foreign-born male/female employment status, it shows a slope downtrend between 20142018. 

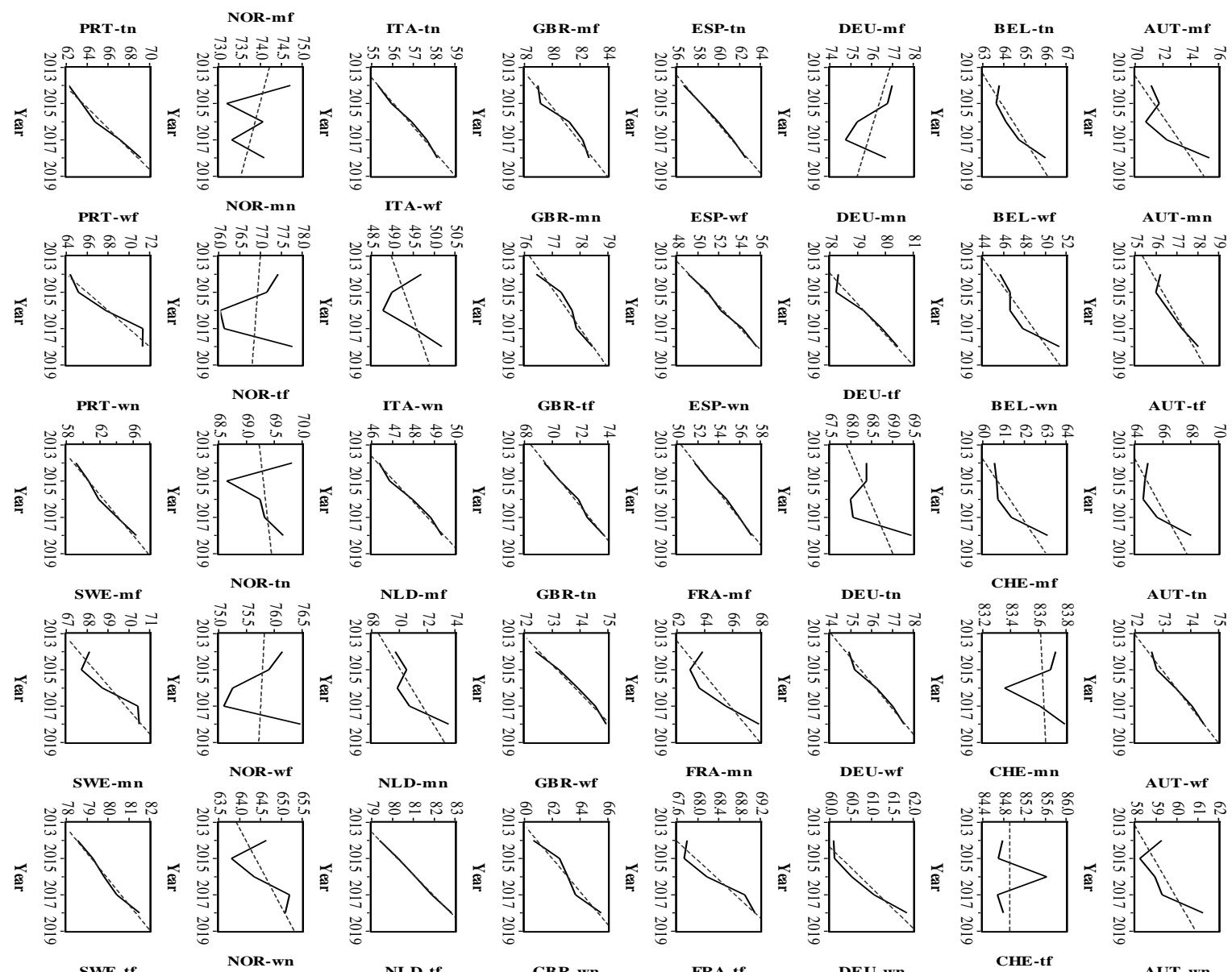

GB R-wf
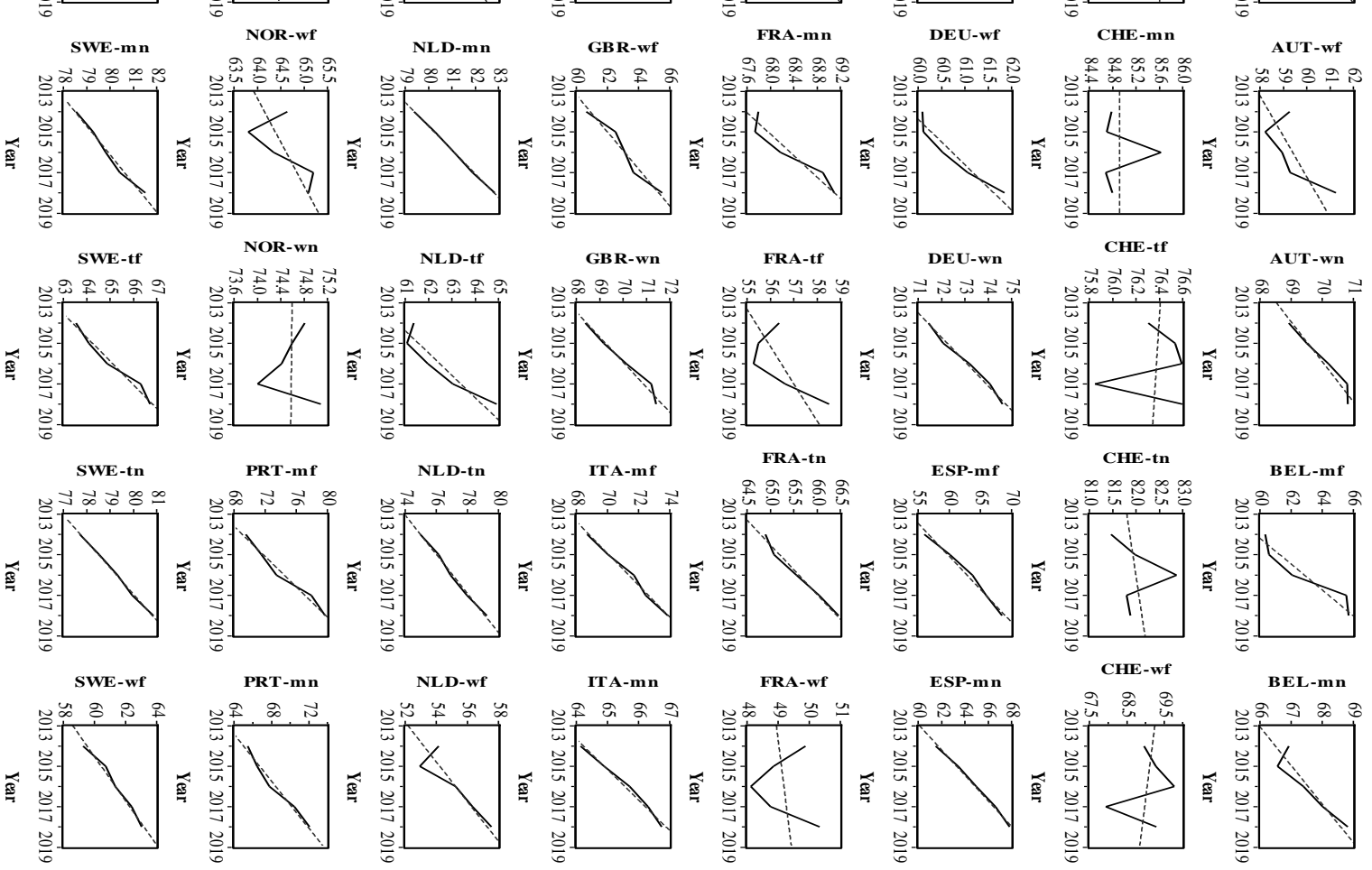

NLD-wf

ITA-mn

FRA-wf

ESP-mn
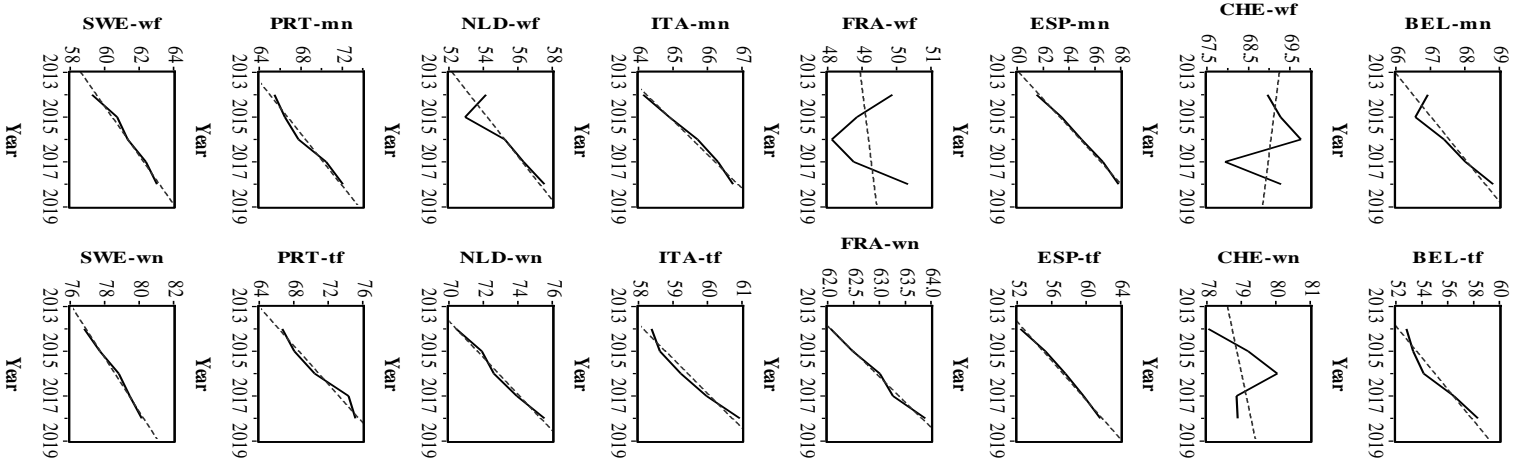

Figure 1. Employment trend in the studied countries between 2014-2018 Source: Author's own compilation (2021) 

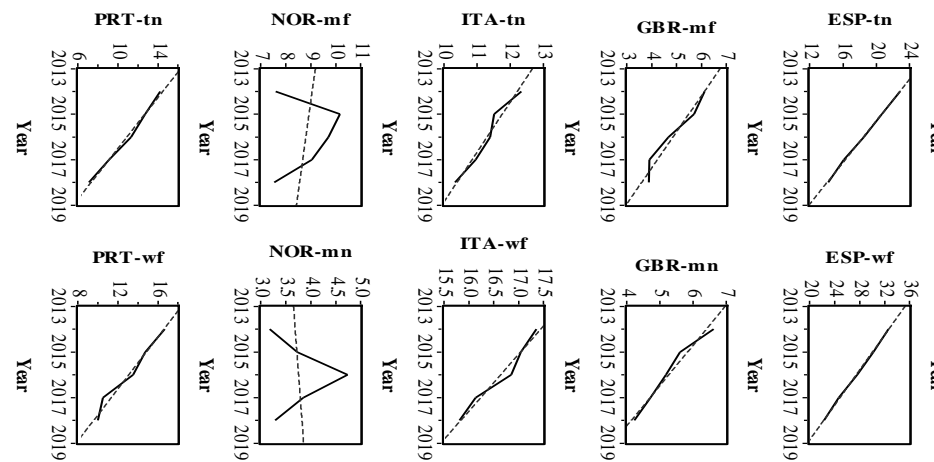

PRT-wn

NOR-tf
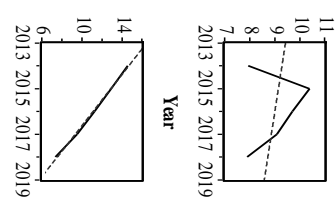

ITA-wn

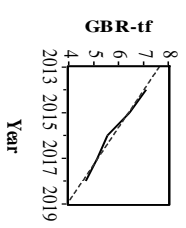

NOR-tn

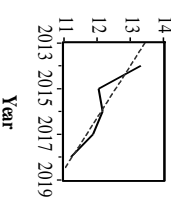

NLD-mf

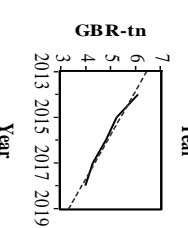

⿶
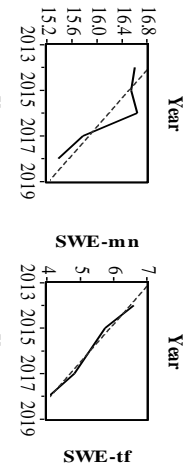

NOR-wf
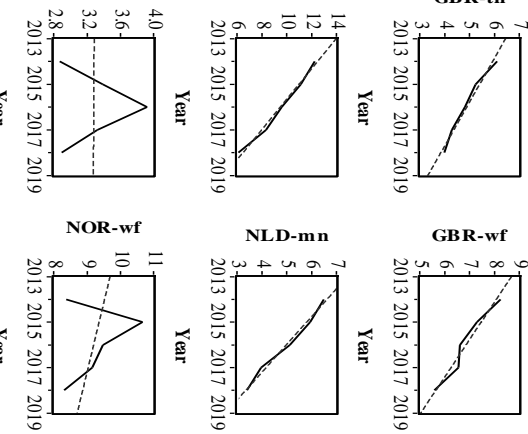

NOR-wn
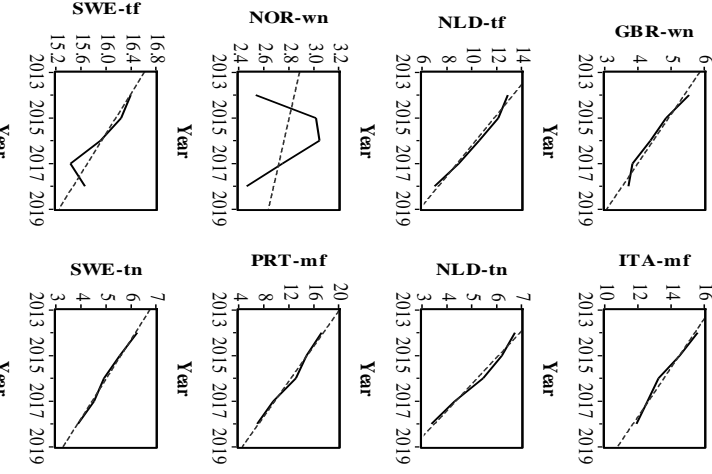

PRT-mf
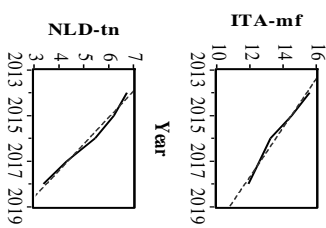

SWE-wf

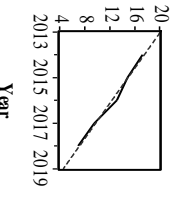

PRT-mn
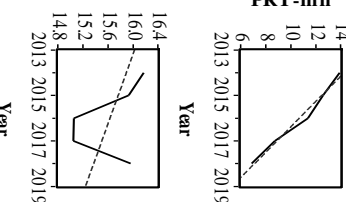

NLD-wf
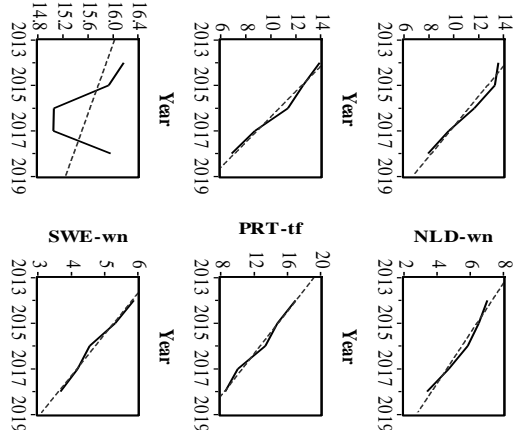

PRT-tf

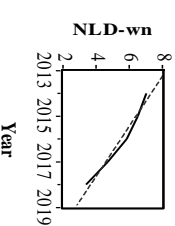

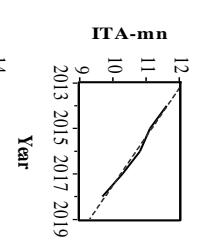

(ITA-tf

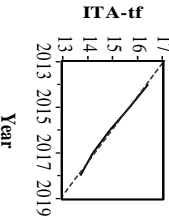

ESP-wf

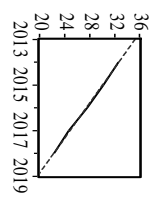

ESP-wn

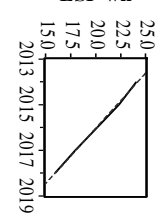

FRA-mf

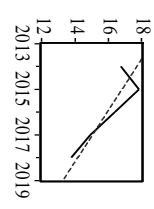

FRA-mn

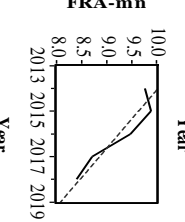

FRA-tf

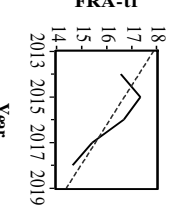

FRA-tn

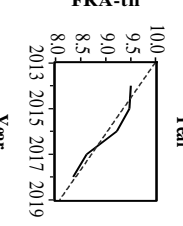

FRA-wf

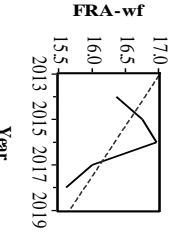

FRA-wn

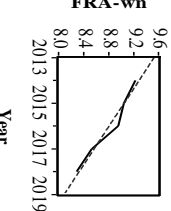

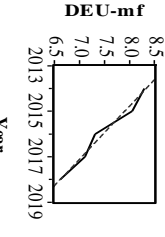

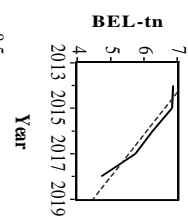

DEU-mn

BEL-wf
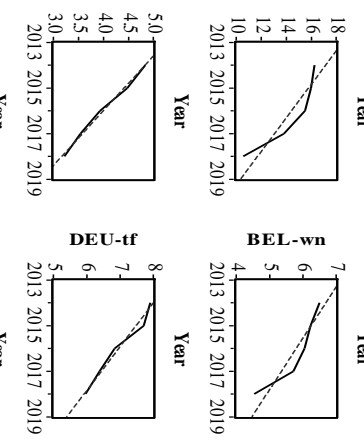

DEU-tn

CHE-mf
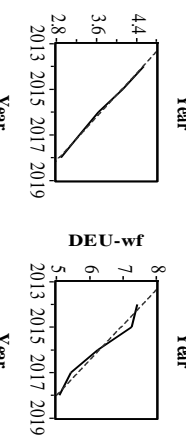

DEU-wn

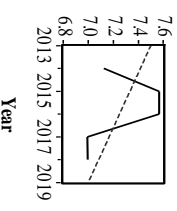

CHE-mn

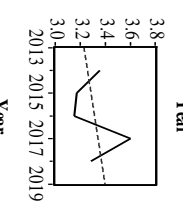

CHE-t
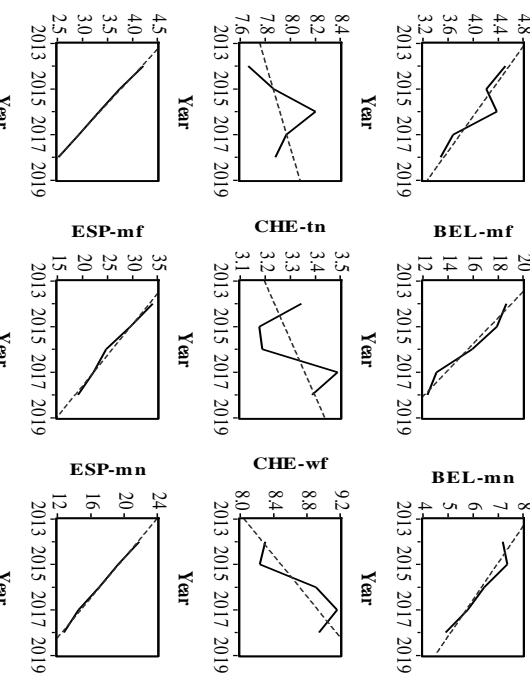

ESP-tf

CHE-wn

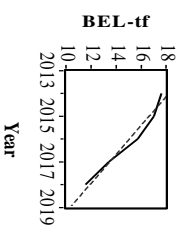

Figure 2. Unemployment trend in the studied countries between 2014-2018

Source: Author's own compilation (2021) 

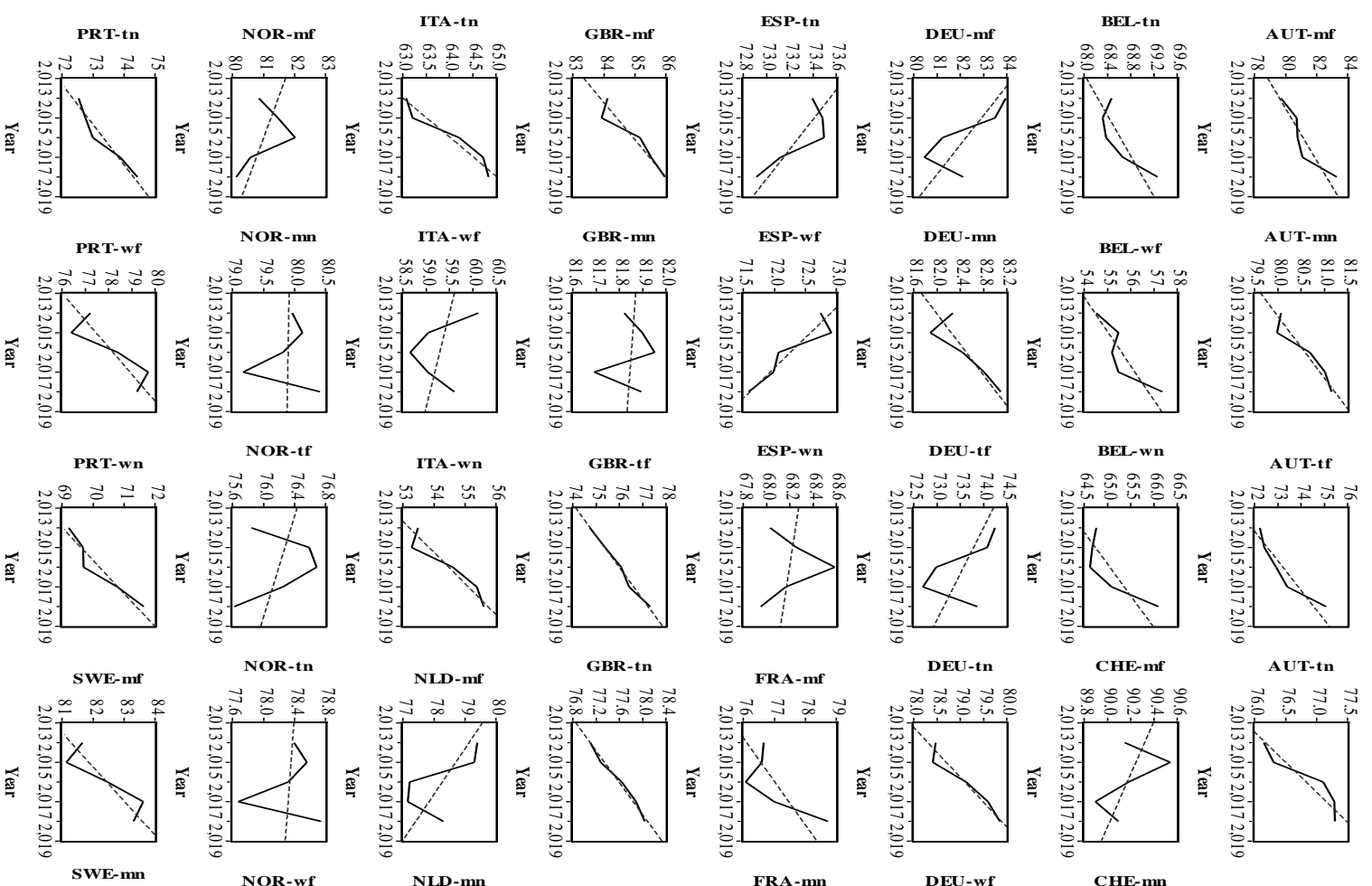

DEU-tn
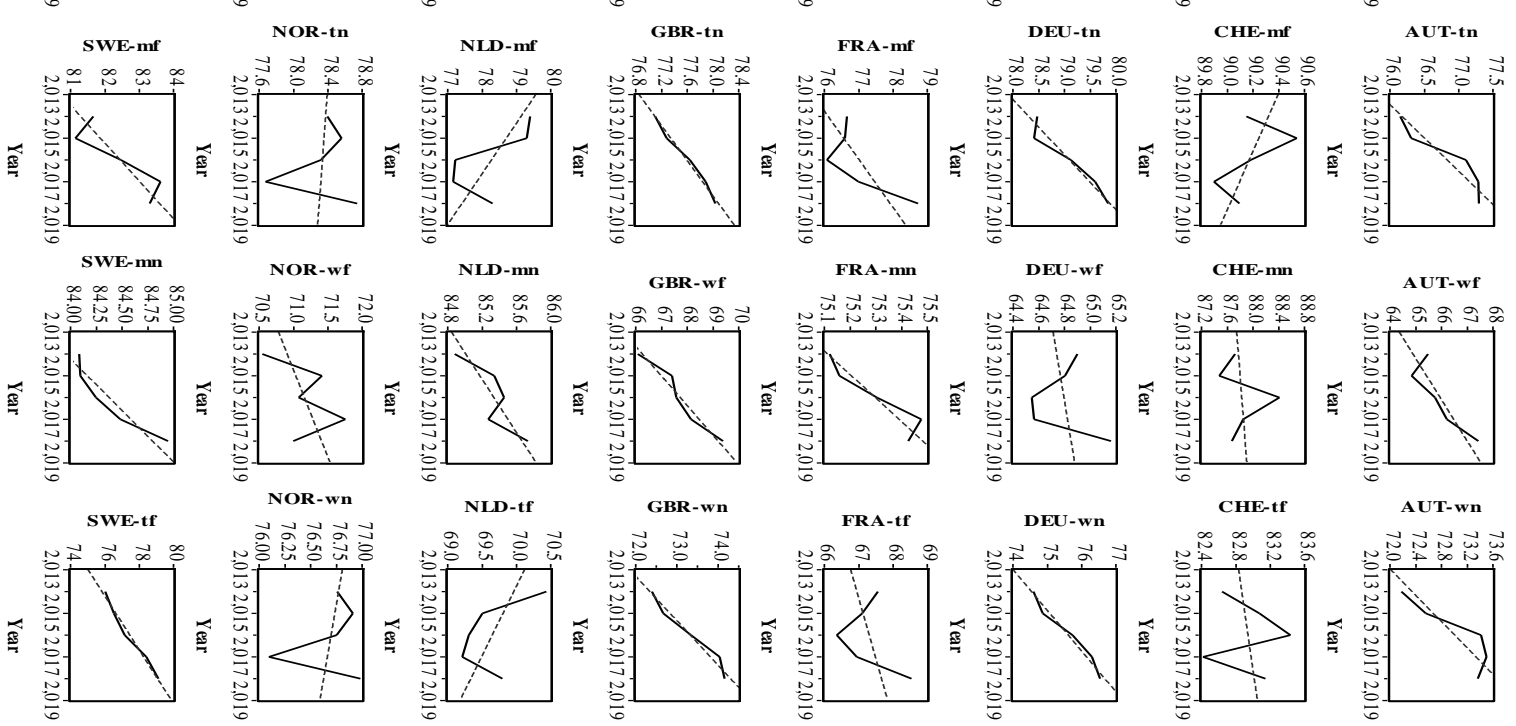

AUT-wn
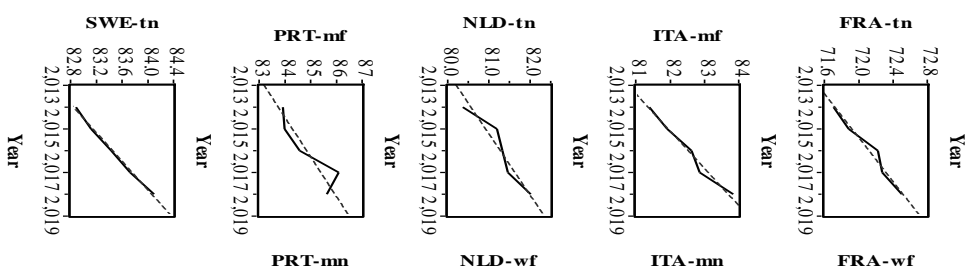

ESP-mf
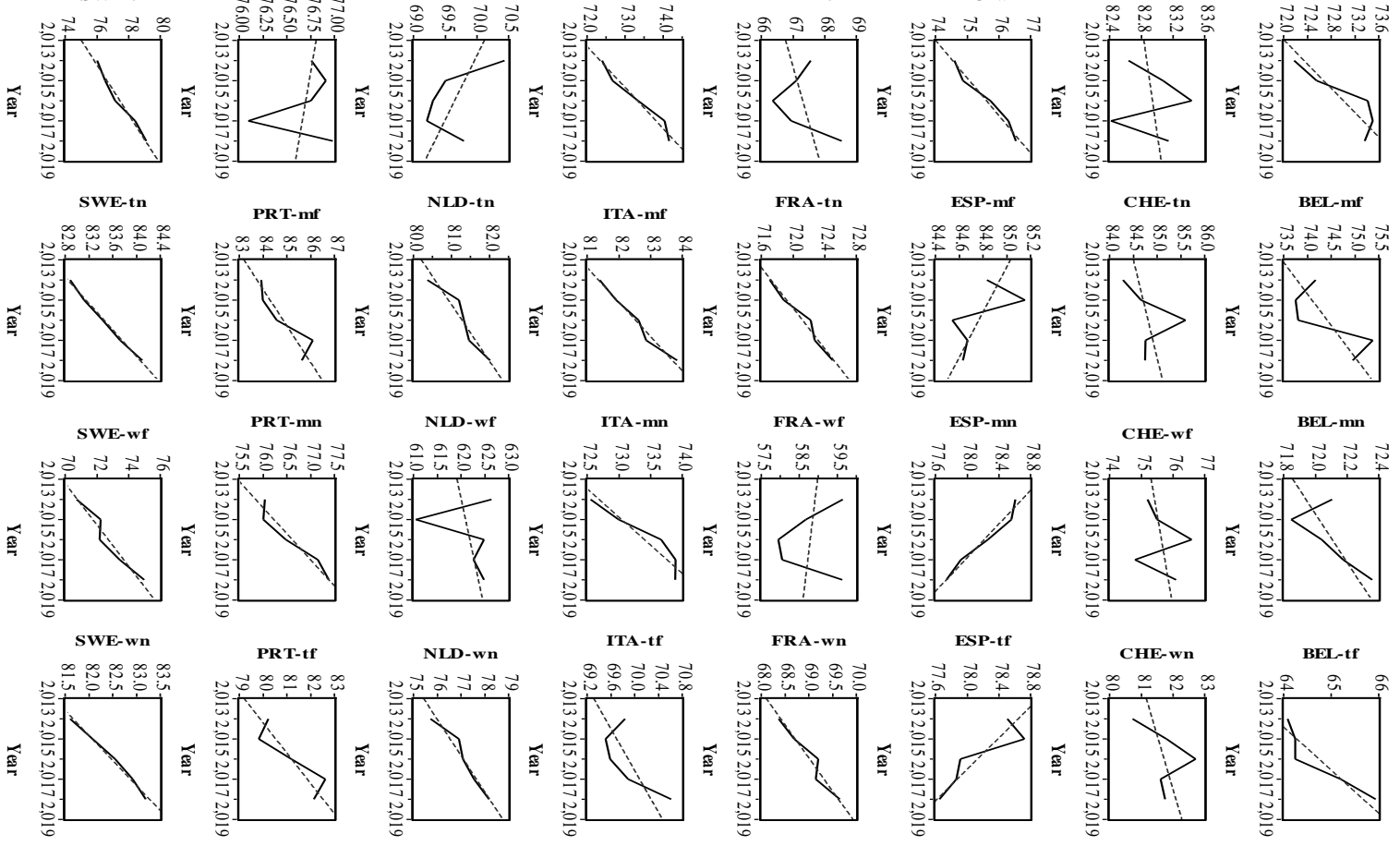

Figure 3. Participation Rate trend in the studied countries between 2014-2018

Source: Author's own compilation (2021) 
Germany (DEU), Spain (ESP), and France (FRA) show a stable trend for foreign and native-born males and females. In both cases, employment status has an upward trend between 2014-2018. Moreover, the United Kingdom (GBR), Italy (ITA), the Netherlands (NLD), Norway (NOR), Portugal (PRT) and Sweden (SWE) also generally have an upward trend in the employment status of native and foreign-born males and females. Appendix 1 shows the linear regression model of employment status.

Figure 2 demonstrates the result of unemployment status trends. It can be easily observed from the table that Western European countries' unemployment status for foreignborn females/males or for native-born females/males has a slope downtrend. However, in the case of Switzerland native-born females and Sweden foreign-born females after 2017, it shows an upwards trend (See Appendix 2 shows the linear regression model of unemployment).

Figure 3 indicates the participation rates of the Western-European countries. As it can be observed from the table, the participation rate of countries shows an upward trend. However, in Switzerland, Spain and Portugal, trends slope down for foreign and native female participants as well as foreign and native male participants (See Appendix 3 for the linear regression model of participation rate).

Note: th stands for Total Native-born, if for Total Foreign-born, mn for Men Nativeborn, mffor Men Foreign-born, wn for Women Native-born, and wffor Women Foreign-born.

\section{Implications of the study}

Labour migration policies are not easy to formulate. They contain many different components, including nativity status differences, gender differences, regional, educational and many other distinctions among migrants, all of which have an influence. This is particularly important because, for effective implication, collaboration is needed at international, bilateral, regional and multidimensional levels, as is a willingness to compromise on the need for such cooperation(Albertsen, 2012).

This study implies that the foreign-born population in Western European countries does not affect the job opportunities of natives. As shown in the analyses, if the number of foreignborn employed increases, the native-born employed will also increase. Based on this, it can be indicated that migrants in a country are not the cause of decreasing employment among the native-born population. Moreover, it is generally taken that someone from a poorer country that succeeds in achieving employment in a wealthy country will be paid more than the natives (Borjas, 2017). However, recent research had shown that even if a migrant gets the same job as a native, at least five years have to pass before he/she earns the same wage as natives workers do (Lopes et al., 2015).

Drinkwater (2017) posited that the employment ratio of the native-born population is higher than that of the foreign-born population. There are differences between countries, as is also indicated in the same research. Concerning the results, foreign-born males have greater rates of unemployment than native-born males in Western-European countries. However, it has been found that if the number of native-born unemployed males or females increases, the number of foreign-born males or females will also increase. This is related to the fact that the country's economic and labour market situation is not related to whether potential employees are native-born or foreign-born. This study implies that the destination countries should create good labour market legislation to decrease unemployment for migrants and the native-born population. Castro-Martín \& Cortina (2015) also mentioned that countries such as Germany, Belgium and the Netherlands have high demands for labour, and low-skilled employment opportunities are required for migrants. As a result, high-skilled migrants cannot find jobs appropriate for their education and skill levels. 
The study also implies differences between native-born males and foreign-born males, native-born females, and foreign-born females in terms of labour status. Previously, foreign labour was highly structured and revolved around male workers(Piper \& Withers, 2018). However, in the last decade, the number of female migrants has also increased rapidly. However, the results indicate that no association has been found between native-born and foreign-born females in many Western European countries in terms of labour status. For example, in France, the Netherlands, Germany, Spain and Austria, there is a need for effective labour market regulation to increase female migrants' participation in the labour market. Finally, once it is recognized that one must consider the interests of potential migrants and not just those of native workers, the magnitude of the gains they would achieve should be discussed in labour migration policy, too (Gallotti, 2009\&Bartram, 2010).

\section{Conclusion}

The purpose of the study was to demonstrate the relationship between native-born males/females and foreign-born males/females in labour market status and participation rates by using Linear Regression in SPSS 23. The first model of the study shows that in Western European countries, such as the UK, France, the Netherlands, Spain, Portugal, Belgium, Austria and Italy, if the foreign-born male population have employment opportunities and start to work, the native-born male population will also have the same options. The results show that the two groups have a significant and positive linear regression with each other.

The unemployed status of the native population is always considered a huge problem in Western-European countries because it was assumed it was caused by the migrant population in these countries. However, it is estimated from the study's findings that if the number of native-born unemployed males increases, the number of foreign-born unemployed males also tends to increase.

Regarding the participation rate, in the Netherlands and Germany, if the native-born male participation rate increases, the foreign-born male participation rate will decrease. However, for other countries such as Spain, Austria, Portugal and Italy, native-born males' and foreign-born males' participation rates are in a significant and positive relationship, i.e., if one increases, the other will increase, too.

It has also been found that in the UK, the Netherlands, Spain, Portugal, Belgium, Austria and Switzerland, employment status increases for native-born females and foreign-born females. However, as regards female unemployment, except in Austria and Switzerland, nativeborn females and foreign-born females are in a significant and positive relationship, i.e., if the number of foreign-born females increases, the number of native-born females will increase, too. Overall, $\mathrm{H} 1$ and $\mathrm{H} 2$ have been partially rejected, and $\mathrm{H} 3$ and $\mathrm{H} 4$ partially accepted. Additionally, as regards the participation rate, when the rate increases for native-born females in the UK, Portugal, Belgium, Austria, and Switzerland, it also rises for foreign-born females.

\section{Author Contributions}

Main Al-Dalahmeh as the lead author, and Krisztina Dajnoki as the second author, have contributed to this article. Main Al-Dalahmeh: conceptualization, theoretical framework, data curation, methodology, writing-original draft, editing, software, formal analysis. Krisztina Dajnoki: conceptualization, review and editing, funding acquisition, supervision. The final paper was read and approved by the authors. 


\section{Acknowledgement}

The publication is supported by the EU-funded Hungarian grant EFOP-3.6.3.-VEKOP16-2017-00007, for the project entitled "From Talent to Young Researchers" - Supporting the Career-developing Activities of Researchers in Higher Education.

\section{References}

Al-Dalahmeh, M., \& Dajnoki, K. (2021). The socio-economic impact of the Syrian refugees influx in Jordan: A systematic review analyses. CrossCultural Management Journal, (2), 145-156. https://cmj.seaopenresearch.eu/volume-xxiii

Al-Dalahmeh, M., Sarihasan, I., \& Dajnoki, K. (2021). The influence of gender and educational attainment differences on international migrants' occupational status in OECD countries. Economies, 9(3), 126.

Albertsen, K. B. (2012). Europeanising labour migration policies and pursuing national objectives. DIIS.

Alshoubaki, W., \& Harris, M. (2021). Multiple streams theory: Insight into the global compact on migration. Journal of International Studies, 14(1), 74-88. doi:10.14254/20718330.2021/14-1/5

Antecol, H., Antecol, \& Heather. (2000). An examination of cross-country differences in the gender gap in labour force participation rates. Labour Economics, 7(4), 409-426.

Bachan, A. (2018). An Exploration of the Gender-Migration-Development Nexus: The Impact of Labor Migration on Women's Empowerment. Consilience: The Journal of Sustainable Development, 20(20), 11-22.

Bartram, D. (2010). The normative foundations of "policy implications": Reflections on international labour migration. Work, Employment and Society, 24(2), 355-365.

Basso, G., \& Peri, G. (2020). Internal Mobility: The Greater Responsiveness of Foreign-Born to Economic Conditions. Journal of Economic Perspectives, 34(3), 77-98.

Bauder, H. (2006). Labor movement: how migration regulates labour markets. Oxford University Press.

Beck, a., Corak, M., \& Tienda, M. (2012). Age at Immigration and the Adult Attainments of child migrants to the United States. The ANNALS of the American Academy of Political and Social Science, 643(1), 134-159.

Bernard, A., \& Bell, M. (2018). Educational selectivity of internal migrants A global assessment. Demographic Research, 39, 835-854.

Bilan, Y. (2017). Migration of the Ukrainian Population. London: Ubiquity Press. DOI: https://doi.org/10.5334/bbg

Bither, J., Ziebarth, A., \& Marshall, G. (2019). German Marshall Fund of the United State How To Upgrade Germany`s Policy Towards African Countries On Migration. Retrievefrom:https://www.gmfus.org/publications/how-upgrade-germanys-policytowards-african countries-migration.

Black, S. E., Schanzenbach, D. W., \& Breitwieser, A. (2017). The recent decline in women's labour force participation. The, 51, 5-17 Retrieved from: https://www.hamiltonproject.org/assets/files/the51percent_ebook.pdf

Borjas, G. J. (2017). The Wage Impact of the Marielitos: A Reappraisal. ILR Review, 70(5), 10771110 .

Cangiano, A. (2014). Migration Policies and Migrant Employment Outcomes. Comparative Migration Studies, 2(4), 417-443. 
Castro-Martín, T., \& Cortina, C. (2015). Demographic Issues of Intra-European Migration: Destinations, Family and Settlement, European Journal of Population, 31(2), 109-125.

Cigagna, C., \& Sulis, G. (2015). On the potential interaction between labour market institutions and immigration policies. International Journal of Manpower.

Clark, K., \& Drinkwater, S. (2008). The labour-market performance of recent migrants. Oxford Review of Economic Policy, 24(3), 495-516.

Cornelson, K. (2016). Immigration, institutions and the labour market. International Labour Organization. Retrieved from: https://www.ilo.org/wcmsp5/groups/public/---europe/--ro-geneva/---ilo-berlin/documents/genericdocument/wcms_556988.pdf

Cseh Papp, I., Bilan, S., \& Dajnoki, K. (2018). Globalization of the labour market - Circular migration in Hungary. Journal of International Studies, 12(2), 182-200. doi:10.14254/2071-8330.2019/12-2/11

Dajnoki, K., Máté, D., Fenyves, V., \& Kun, A. I. (2017). Deconstructing attitudes towards immigrant workers among Hungarian employees and higher education students. Sustainability, 9(9), 1639.

Drinkwater, S. (2017). Why does unemployment differ for immigrants? IZA World of Labor.Faggian, A., Rajbhandari, I., \& Dotzel, K. R. (2017). The interregional migration of human capital and its regional consequences: a review. Regional Studies, 51(1), 128143.

Fassmann, H., \& Munz, R. (1992). Patterns and trends of international migration in Western Europe. The Population and Development Review, 457-480.

Gallotti, M. (2009). The gender dimension of domestic work in Western Europe. ILO.

Gheasi, M., \& Nijkamp, P. (2017). A Brief Overview of International Migration Motives and impacts, with Specific Reference to FDI. Economies, 5(3), 31.

Hall, M., \& Farkas, G. (2008). Does human capital raise earnings for immigrants in the lowskill labour market? Demography, 45(3), 619-639.

Hanson, G. H. (2009). The Economic Consequences of the International Migration of Labor. Annual Review of Economics, 1(1), 179-208.

Hempstead, K. (2007). Mobility of the Foreign-Born Population in the United States, 19952000: The Role of Gateway States. International Migration Review, 41(2), 466-479.

Hidalgo, B., \& Goodman, M. (2013). Multivariate or multivariable regression? American journal of public health, 103(1), 39-40

Jennissen, R., \& Van Wissen, L. (n.d.). The distribution of asylum seekers over Northern and Western European countries, 1985-2005. Source: Genus, 71(1), 109-132.

Jouke van Dijk and Hendrik Folmer. (2019). The Consequences of Interregional LaborMigration for the Regional Labor Market: Theory, Methodology and Dutch Experience.The Review of Economics and Statistics, 68(1), 74-83.

Kang, Y., \& Kim, B.-Y. (2018). Immigration and economic growth: do origin and destination matter? Applied Economics, 50(46), 4968-4984.

Kofman, E. (2000). The invisibility of skilled female migrants and gender relations in studies of skilled migration in Europe. International Journal of Population Geography, 6(1), 4559.

Lang, G. (2000). Native-immigrant wage differentials in Germany: Assimilation, discrimination, or human capital? (No. 197). Volkswirtschaftliche Diskussionsreihe, Institutfür Volkswirtschaftslehre der Universität Augsburg.

Lemmermann, D., \& Riphahn, R. T. (2018). The causal effect of age at migration on youth educational attainment. Economics of Education Review, 63, 78-99.

Lopes, M., Gielen, A., \& Lopes, M. (2015). How Immigrants Affect the UK Natives' Wages Evidence from the 2004 EU Enlargement. 
Lucas, R. E. B. (2007). Migration and Rural Development. EJADE: Electronic Journal of Agricultural and Development Economics, 4(1), 99-122.

Máté, D., Sarihasan, I., Popp, J., \& Oláh, J. (2018). The role of regional differences in immigration: The case of OECD countries. Economics \& Sociology, 11(3), 190-206.

Máté, D., Sarıhasan, İ., \& Dajnoki, K. (2017). The relations between labour market institutions and employment of migrants. Amfiteatru Economic, 19(46), 806.

Oláh, J., Halasi, G., Szakály, Z., Popp, J., \& Balogh, P. (2017). The impact of international migration on the labour market-A case study from Hungary. Amfiteatru Economic, 19(46), 790.

Piper, N., \& Withers, M. (2018). Forced transnationalism and temporary labour migration: implications for understanding migrant rights. Identities, 25(5), 558-575.

Raghuram, P. (2008). Migrant women in male-dominated sectors of the labour market: a research agenda. Population, Space and Place, 14(1), 43-57.

Rangelova, R. (2009). Labour migration from east to west in the context of European Union integration. SEER-South-East Europe Review for Labour and Social Affairs, (01), 33-56.

Remenyi, D., Williams, B., Money, A., \& Swartz, E. (1998). Doing research in business and management: an introduction to process and method. Sage Books.

Rendall, M. S., \& Parker, S. W. (2014). Two decades of negative educational selectivity of Mexican migrants to the United States. Population and Development Review, 40(3), 421446.

Rubery, J. (2015). Structured Labour Markets, Worker Organisation, and Low Pay. Classes, Power, and Conflict, 2(1), 330-348.

Rienzo, C. (2016). Characteristics and outcomes of migrants in the UK labour market. Migration Observatory Briefing, COMPAS, University of Oxford, 1-10.

Sarihasan, I. (2016). Immigration Growth Tendencies in OECD Countries. SEA-Practical Application of Science, 4(12), 547-553.

Sarihasan, I. (2017). The gender differences of immigration in OECD countries. Annals of Faculty of Economics, 1(1), 697-706.

Sobotka, T. (2009). Migration continent Europe. Vienna Yearbook of Population Research, 217-233.

Stuhler, J., Thomasen, H., \& Zimmermann, K. F. (2008). Geographic Mobility in the European Union: Optimising its Economic and Social Benefits.

Tanaka, H., Hayashi, I., \& Watada, J. (1989). Possibilistic. Linear regression analysis for fuzzy data. European Journal of Operational Research, 40(3), 389- 396.

Uyanık, G. K., \& Güler, N. (2013). A Study on Multiple Linear Regression Analysis. ProcediSocial and Behavioral Sciences, 106, 234-240.

Vadean, F., Randazzo, T., \& Piracha, M. (2019). Remittances, Labour Supply and Activity of Household Members Left-Behind. Journal of Development Studies, 55(2), 278-293.

Van de Werfhorst, H. G., \& Heath, A. (2019). Selectivity of Migration and the Educational Disadvantages of Second-Generation Immigrants in Ten Host Societies. European Journal of Population, 35(2), 347-378.

Wang, H., Guo, F., \& Cheng, Z. (2015). A distributional analysis of wage discrimination against migrant workers in China's urban labour market. Urban Studies, 52(13), 2383-2403.

Wang, S., \& Coulter, R. (2019). Exploring Ethnic and Generational Differences in Gender Role Attitudes among Immigrant Populations in Britain: The Role of Neighborhood Ethnic Composition. International Migration Review, 53(4), 1121-1147.

Willis, K. G. (1975). Regression models of migration: an econometric reappraisal of some techniques. Geografiska Annaler: Series B, Human Geography, 57(1), 42-54. 


\section{Appendices}

Table A.1. Linear regression model for employment status

\section{Employment Rate}

Country

AUT-tn

AUT-tf

AUT-mn

AUT-mf

AUT-wn

AUT-wf

BEL-tn

BEL-tf

BEL-mn

BEL-mf

BEL-wn

BEL-wf

CHE-tn

CHE-tf

CHE-mn

CHE-mf

CHE-wn

CHE-wf

DEU-tn

DEU-tf

DEU-mn

DEU-mf

DEU-wn

DEU-wf

ESP-tn

ESP-tf

ESP-mn

ESP-mf

ESP-wn

ESP-wf

FRA-tn

FRA-tf

FRA-mn

FRA-mf

FRA-wn

FRA-wf

GBR-tn

GBR-tf

GBR-mn

GBR-mf

GBR-wn

GBR-wf

ITA-tn

ITA-tf

ITA-mn

ITA-mf

\section{Liner Equation}

$y=0.5025 x-939.61$

$y=0.7141 x-1374.2$

$y=0.4913 x-913.75$

$\mathrm{y}=0.896 \mathrm{x}-913.75$

$\mathrm{y}=0.5086 \mathrm{x}-955.63$

$\mathrm{y}=0.5022 \mathrm{x}-952.96$

$\mathrm{y}=0.5518 \mathrm{x}-1048$

$\mathrm{y}=1.4234 \mathrm{x}-2814.5$

$\mathrm{y}=0.5251 \mathrm{x}-991.07$

$y=1.5706 x-3103.5$

$\mathrm{y}=0.5823 \mathrm{x}-1112.6$

$\mathrm{y}=1.2562 \mathrm{x}-2484.4$

$y=0.0649 x-48.912$

$\mathrm{y}=0.0108 \mathrm{x}+98.245$

$y=0.0006 x+83.375$

$\mathrm{y}=0.006 \mathrm{x}+71.464$

$\mathrm{y}=0.1368 \mathrm{x}-196.81$

$y=0.0679 x+206$

$y=0.7121 x-1359.5$

$y=0.1854 x-305.28$

$\mathrm{y}=0.5912 \mathrm{x}-1112.7$

$\mathrm{y}=0.2633 \mathrm{x}+606.82$

$\mathrm{y}=0.8345 \mathrm{x}-1609.2$

$\mathrm{y}=0.4465 \mathrm{x}-839.51$

$\mathrm{y}=1.4889 \mathrm{x}-2941.2$

$\mathrm{y}=2.2873 \mathrm{x}-4554$

$\mathrm{y}=1.5881 \mathrm{x}-3136.7$

$y=3.0814 x-6149.4$

$\mathrm{y}=1.3831 \mathrm{x}-2733.9$

$\mathrm{y}=1.6443 \mathrm{x}-3262.6$

$\mathrm{y}=0.4097 \mathrm{x}-760.4$

$\mathrm{y}=0.545 \mathrm{x}-1042.3$

$\mathrm{y}=0.3778 \mathrm{x}-693.39$

$\mathrm{y}=1.0691 \mathrm{x}-2090.5$

$y=0.4423 x-828.64$

$\mathrm{y}=0.0807 \mathrm{x}-113.49$

$\mathrm{y}=0.6388 \mathrm{x}-1214$

$y=1.0538 x-2052.8$

$y=0.4578 x-845.41$

$\mathrm{y}=1.0393 \mathrm{x}-2014.4$

$\mathrm{y}=0.8109 \mathrm{x}-1564.6$

$y=1.0971 x-2148.7$

$\mathrm{y}=0.7396 \mathrm{x}-1434.2$

$\mathrm{y}=0.648 \mathrm{x}-1247$

$\mathrm{y}=0.6632 \mathrm{x}-1271.5$

$y=1.2741 x-2497.3$

\section{$\mathbf{R}^{2}$}

0.9783

0.6176

0.8743

0.6041

0.9435

0.5007

0.8262

0.9330

0.8523

0.8967

0.7424

0.8037

0.0348

0.0029

9E-06

0.0032

0.0903

0.0248

0.9753

0.2456

0.9376

0.1713

0.9871

0.9088

0.9958

0.9933

0.9946

0.9842

0.9950

0.9949

0.9830

0.4487

0.9009

0.7201

0.9881

0.0202

0.9840

0.9911

0.9350

0.9340

0.9706

0.9489

0.9905

0.9585

0.9867

0.9904 
RECENT ISSUES IN SOCIOLOGICAL RESEARCH

\begin{tabular}{|c|c|c|}
\hline ITA-wn & $y=0.7957 x-1556.3$ & 0.9865 \\
\hline ITA-wf & $y=0.1526 x-258.13$ & 0.1822 \\
\hline NLD-tn & $y=1.0369 x-2013.3$ & 0.9933 \\
\hline NLD-tf & $y=0.9078 x-1769.5$ & 0.8444 \\
\hline NLD-mn & $y=0.8528 x-1638.2$ & 0.9993 \\
\hline NLD-mf & $y=0.7924 x-1526.7$ & 0.6472 \\
\hline NLD-wn & $y=1.2273 x-2401.5$ & 0.9854 \\
\hline NLD-wf & $y=1.0193 x-1999.8$ & 0.8006 \\
\hline NOR-tn & $y=0.0166 x+109.24$ & 0.0020 \\
\hline NOR-tf & $y=0.0367 x-4.6021$ & 0.0162 \\
\hline NOR-mn & $y=0.0325 x+142.36$ & 0.0042 \\
\hline NOR-mf & $y=0.1137 x+303.06$ & 0.0819 \\
\hline NOR-wn & $y=0.0034 x+81.464$ & 0.0002 \\
\hline NOR-wf & $y=0.2317 x-402.48$ & 0.4119 \\
\hline PRT-tn & $y=1.7528 x-3468.2$ & 0.9808 \\
\hline PRT-tf & $y=2.3266 x-4619.6$ & 0.9623 \\
\hline PRT-mn & $y=1.7219 x-3403$ & 0.9733 \\
\hline PRT-mf & $y=2.6834 x-5335.3$ & 0.9754 \\
\hline PRT-wn & $y=1.7881 x-3542.4$ & 0.9826 \\
\hline PRT-wf & $y=2.0071 x-3978.4$ & 0.9279 \\
\hline SWE-tn & $y=0.7713 x-1475.8$ & 0.9977 \\
\hline SWE -tf & $y=0.8577 x-1664.1$ & 0.9689 \\
\hline SWE -mn & $y=0.7072 x-1345.9$ & 0.9813 \\
\hline SWE -mf & $y=0.7483 x-1439.4$ & 0.8338 \\
\hline SWE -wn & $y=0.8381 x-1610.9$ & 0.9899 \\
\hline SWE -wf & $y=0.9148 x-1783$ & 0.9779 \\
\hline
\end{tabular}


Table A.2. Linear regression model for unemployment status

\begin{tabular}{|c|c|c|}
\hline \multicolumn{3}{|c|}{ Unemployment Rate } \\
\hline Country & Liner Equation & $\mathbf{R}^{2}$ \\
\hline AUT-tn & $y=0.2459 x+500.19$ & 0.7365 \\
\hline AUT-tf & $y=0.1566 x+1374.2$ & 0.1057 \\
\hline AUT-mn & $y=0.232 x+472.44$ & 0.5538 \\
\hline AUT-mf & $y=0.896 x+546.56$ & 0.1731 \\
\hline AUT-wn & $y=0.2617 x+531.67$ & 0.8331 \\
\hline AUT-wf & $y=0.0327 x+84.858$ & 0.0104 \\
\hline BEL-tn & $y=0.538 x+1090.7$ & 0.9112 \\
\hline BEL-tf & $y=1.5791 x+9198.6$ & 0.9579 \\
\hline BEL-mn & $y=0.6197 x-1255.7$ & 0.9107 \\
\hline BEL-mf & $y=1.7459 x+3535.3$ & 0.9603 \\
\hline BEL-wn & $y=0.444 x+900.84$ & 0.8433 \\
\hline BEL-wf & $y=1.3613 x-2758.8$ & 0.8287 \\
\hline CHE-tn & $y=0.0402 x-77.738$ & 0.2238 \\
\hline CHE-tf & $y=0.0536 x-100.21$ & 0.1887 \\
\hline CHE-mn & $y=0.028 x-53.213$ & 0.0596 \\
\hline CHE-mf & $y=0.0835 x+175.49$ & 0.0200 \\
\hline CHE-wn & $y=0.0536 x-104.77$ & 0.4532 \\
\hline CHE-wf & $y=0.2218 x-438.47$ & 0.7080 \\
\hline DEU-tn & $y=-0.419 x+848.37$ & 0.9979 \\
\hline DEU-tf & $y=0.5197 x+1054.7$ & 0.9721 \\
\hline DEU-mn & $y=0.4167 x+843.98$ & 0.9330 \\
\hline DEU-mf & $y=0.4289 x+872.18$ & 0.9714 \\
\hline DEU-wn & $y=0.4204 x+850.82$ & 0.9988 \\
\hline DEU-wf & $y=0.6473 x-1311.3$ & 0.9586 \\
\hline ESP-tn & $y=-2.1817 x+4416.8$ & 0.9990 \\
\hline ESP-tf & $y=-3.1684 x+6414.1$ & 0.9947 \\
\hline ESP-mn & $y=-2.2845 x+4622.6$ & 0.9970 \\
\hline ESP-mf & $y=-3.7126 x+7510.6$ & 0.9834 \\
\hline ESP-wn & $y=-2.0634 x+4179.8$ & 0.9984 \\
\hline ESP-wf & $y=-2.604 x+5277.2$ & 0.9985 \\
\hline FRA-tn & $y=-0.3176 x+649.31$ & 0.9178 \\
\hline FRA-tf & $y=-0.5805 x+1186.5$ & 0.7109 \\
\hline FRA-mn & $y=-0.3901 x+795.74$ & 0.8809 \\
\hline FRA-mf & $y=-0.8872 x+1804.5$ & 0.7693 \\
\hline FRA-wn & $y=-0.2397 x+492.04$ & 0.9517 \\
\hline FRA-wf & $y=-0.2263 x+472.55$ & 0.4225 \\
\hline GBR-tn & $y=-0.5208 x+1054.8$ & 0.9678 \\
\hline GBR-tf & $y=-0.6164 x+1248.4$ & 0.9791 \\
\hline GBR-mn & $y=-0.5665 x+1174.3$ & 0.9663 \\
\hline GBR-mf & $y=-0.6313 x+1277.5$ & 0.9340 \\
\hline GBR-wn & $y=-0.4678 x+975.54$ & 0.9706 \\
\hline GBR-wf & $y=-0.6079 x+1232.5$ & 0.9436 \\
\hline ITA-tn & $y=-0.4553 x+929.14$ & 0.9573 \\
\hline ITA-tf & $y=-0.6906 x+1407.3$ & 0.9938 \\
\hline ITA-mn & $y=-0.4697 x+957.51$ & 0.9887 \\
\hline ITA-mf & $y=-0.9324 x+1893.3$ & 0.9795 \\
\hline ITA-wn & $y=-0.439 x+897.21$ & 0.8244 \\
\hline ITA-wf & $y=-0.4016 x+826.32$ & 0.9608 \\
\hline
\end{tabular}


RECENT ISSUES IN SOCIOLOGICAL RESEARCH

\begin{tabular}{lll}
\hline NLD-tn & $\mathrm{y}=-0.8604 \mathrm{x}+1739.8$ & 0.9829 \\
\hline NLD-tf & $\mathrm{y}=-1.5006 \mathrm{x}+3035.6$ & 0.9785 \\
\hline NLD-mn & $\mathrm{y}=-0.8167 \mathrm{x}+1638.2$ & 0.9858 \\
\hline NLD-mf & $\mathrm{y}=-1.5011 \mathrm{x}+3035.7$ & 0.9850 \\
\hline NLD-wn & $\mathrm{y}=-0.9114 \mathrm{x}+1848$ & 0.9640 \\
\hline NLD-wf & $\mathrm{y}=-1.5077 \mathrm{x}+3035.7$ & 0.9578 \\
\hline NOR-tn & $\mathrm{y}=-0.0014 \mathrm{x}+6.1942$ & $3 \mathrm{E}-05$ \\
\hline NOR-tf & $\mathrm{y}=-0.1414 \mathrm{x}+294$ & 0.0418 \\
\hline NOR-mn & $\mathrm{y}=0.0339 \mathrm{x}-64.666$ & 0.0076 \\
\hline NOR-mf & $\mathrm{y}=-0.1257 \mathrm{x}+262.21$ & 0.0272 \\
\hline NOR-wn & $\mathrm{y}=-0.0414 \mathrm{x}+86.204$ & 0.0599 \\
\hline NOR-wf & $\mathrm{y}=-0.1643 \mathrm{x}+340.48$ & 0.0733 \\
\hline PRT-tn & $\mathrm{y}=-1.7908 \mathrm{x}+3621.2$ & 0.9916 \\
\hline PRT-tf & $\mathrm{y}=-2.1528 \mathrm{x}+4352.8$ & 0.9856 \\
\hline PRT-mn & $\mathrm{y}=-1.7954 \mathrm{x}+3630.2$ & 0.9790 \\
\hline PRT-mf & $\mathrm{y}=-2.5933 \mathrm{x}+5240.5$ & 0.9877 \\
\hline PRT-wn & $\mathrm{y}=-1.7877 \mathrm{x}+3615.1$ & 0.9970 \\
\hline PRT-wf & $\mathrm{y}=-1.7569 \mathrm{x}+3555.1$ & 0.9671 \\
\hline SWE-tn & $\mathrm{y}=-0.5778 \mathrm{x}+1169.9$ & 0.9927 \\
\hline SWE -tf & $\mathrm{y}=-0.2284 \mathrm{x}+476.29$ & 0.8118 \\
\hline SWE -mn & $\mathrm{y}=-0.6003 \mathrm{x}+1215.5$ & 0.9850 \\
\hline SWE -mf & $\mathrm{y}=-0.3213 \mathrm{x}+663.98$ & 0.7769 \\
\hline SWE -wn & $\mathrm{y}=-0.5521 \mathrm{x}+1117.7$ & 0.9879 \\
\hline SWE -wf & $\mathrm{y}=-0.1309 \mathrm{x}+279.48$ & 0.1460 \\
\hline & &
\end{tabular}


Table A.3. Linear regression model for participation rate status

\begin{tabular}{|c|c|c|}
\hline \multicolumn{3}{|c|}{ Participation Rate } \\
\hline Country & Liner Equation & $\mathbf{R}^{2}$ \\
\hline AUT-tn & $y=0.3277 x-583.87$ & 0.8638 \\
\hline AUT-tf & $y=0.6646 x-1266.7$ & 0.8601 \\
\hline AUT-mn & $y=0.3187 x-561.91$ & 0.8923 \\
\hline AUT-mf & $y=0.7569 x-1444.8$ & 0.8103 \\
\hline AUT-wn & $y=0.3312 x-549.79$ & 0.7718 \\
\hline AUT-wf & $y=0.5278 x-998.08$ & 0.7418 \\
\hline BEL-tn & $y=0.1931 x-320.7$ & 0.6313 \\
\hline BEL-tf & $y=0.4446 x-875.95$ & 0.8474 \\
\hline BEL-mn & $y=0.083 x-95.258$ & 0.4921 \\
\hline BEL-mf & $y=0.3183 x-567.21$ & 0.4861 \\
\hline BEL-wn & $y=0.9093 x-558.57$ & 0.6360 \\
\hline BEL-wf & $y=0.5725 x-1098.5$ & 0.7242 \\
\hline CHE-tn & $y=0.1024 x-121.66$ & 0.1131 \\
\hline CHE-tf & $y=0.0363 x+9.7199$ & 0.0196 \\
\hline CHE-mn & $y=0.0262 x+34.945$ & 0.0136 \\
\hline CHE-mf & $y=0.0746 x+240.64$ & 0.2567 \\
\hline CHE-wn & $y=0.1869 x+294.99$ & 0.1756 \\
\hline CHE-wf & $y=0.1087 x-143.5$ & 0.0580 \\
\hline DEU-tn & $y=0.3952 x-717.72$ & 0.9260 \\
\hline DEU-tf & $y=0.2135 x+504.06$ & 0.2392 \\
\hline DEU-mn & $y=0.2574 x+436.36$ & 0.7509 \\
\hline DEU-mf & $y=0.6686 x+1430.1$ & 0.5171 \\
\hline DEU-wn & $y=0.5348 x+1002.5$ & 0.9643 \\
\hline DEU-wf & $y=0.028 x+8.4351$ & 0.0300 \\
\hline ESP-tn & $y=-0.1322 x+339.72$ & 0.6723 \\
\hline ESP-tf & $y=-0.2568 x+595.88$ & 0.7850 \\
\hline ESP-mn & $y=-0.239 x+560.08$ & 0.9598 \\
\hline ESP-mf & $y=-0.0889 x+264.03$ & 0.3421 \\
\hline ESP-wn & $y=-0.0259 x+120.38$ & 0.0275 \\
\hline ESP-wf & $y=-0.3257 x+728.96$ & 0.8578 \\
\hline FRA-tn & $y=0.1985 x-328.09$ & 0.9655 \\
\hline FRA-tf & $y=0.1799 x-295.35$ & 0.1219 \\
\hline FRA-mn & $y=0.0926 x-111.4$ & 0.8675 \\
\hline FRA-mf & $y=0.4518 x-833.89$ & 0.4960 \\
\hline FRA-wn & $y=0.3035 x-542.79$ & 0.9325 \\
\hline FRA-wf & $y=0.0637 x-187.25$ & 0.0150 \\
\hline GBR-tn & $y=0.2471 x-420.63$ & 0.9826 \\
\hline GBR-tf & $y=0.6219 x-1177.8$ & 0.9867 \\
\hline GBR-mn & $y=0.5665 x-1174.3$ & 0.0094 \\
\hline GBR-mf & $y=0.5292 x-981.96$ & 0.8938 \\
\hline GBR-wn & $y=0.4903 x-915.08$ & 0.9606 \\
\hline GBR-wf & $y=0.7363 x-1416.6$ & 0.9349 \\
\hline ITA-tn & $y=0.5055 x-955.07$ & 0.9232 \\
\hline ITA-tf & $y=0.1928 x-318.75$ & 0.4902 \\
\hline ITA-mn & $y=0.3572 x-646.81$ & 0.8876 \\
\hline ITA-mf & $y=0.5845 x-1095.9$ & 0.9722 \\
\hline ITA-wn & $y=0.6333 x-1222.2$ & 0.8892 \\
\hline ITA-wf & $y=-0.1044 x+269.81$ & 0.0826 \\
\hline
\end{tabular}


RECENT ISSUES IN SOCIOLOGICAL RESEARCH

\begin{tabular}{|c|c|c|}
\hline NLD-tn & $y=0.3561 x-636.67$ & 0.8987 \\
\hline NLD-tf & $y=0.1567 x-385.46$ & 0.2547 \\
\hline NLD-mn & $y=0.1642 x-245.75$ & 0.6982 \\
\hline NLD-mf & $y=-0.4301 x+945.34$ & 0.3951 \\
\hline NLD-wn & $y=0.5564 x-1041$ & 0.9334 \\
\hline NLD-wf & $y=0.09 x-119.27$ & 0.0481 \\
\hline NOR-tn & $y=-0.0187 x+115.98$ & 0.0053 \\
\hline NOR-tf & $y=-0.0781 x+233.62$ & 0.0718 \\
\hline NOR-mn & $y=0.0061 x+92.1$ & 0.0004 \\
\hline NOR-mf & $y=-0.235 x+554.78$ & 0.2477 \\
\hline NOR-wn & $y=-0.0364 x+149.99$ & 0.0265 \\
\hline NOR-wf & $y=0.1251 x-181.13$ & 0.1875 \\
\hline PRT-tn & $y=0.49 x-914.53$ & 0.9331 \\
\hline PRT-tf & $y=0.6626 x-1254.6$ & 0.7632 \\
\hline PRT-mn & $y=0.3857 x-700.92$ & 0.9203 \\
\hline PRT-mf & $y=0.5505 x-1024.9$ & 0.7892 \\
\hline PRT-wn & $y=0.5953 x+1130$ & 0.9058 \\
\hline PRT-wf & $y=0.7284 x+1390.3$ & 0.7051 \\
\hline SWE-tn & $y=0.3044 x-530.18$ & 0.9948 \\
\hline SWE -tf & $y=0.8102 x-1556$ & 0.9768 \\
\hline SWE -mn & $y=0.2113 x-341.71$ & 0.8609 \\
\hline SWE -mf & $y=0.5759 x-1078.5$ & 0.7522 \\
\hline SWE -wn & $y=0.4022 x-728.45$ & 0.9882 \\
\hline SWE -wf & $y=-0.7859 x-1894$ & 0.9313 \\
\hline
\end{tabular}

